\title{
2. Temperature and Salinity
}

\section{Key points}

\section{i. Introduction}

Marine temperatures are important to the UK maritime climate and to the marine ecosystem. Some species are sensitive to salinity and may be affected by changes. Adjacent Atlantic temperature and salinity are controlled by the large-scale circulation and history of these waters (ultimately coupled with atmospheric weather and climate). Shelf-sea temperature is controlled primarily by mixing and local weather, with some influence of Atlantic water near where it moves onto the shelf. Temperature has a strong seasonal cycle, larger in shallow water; summer maxima decrease from south to north. Summer stratification (i.e. warmer water near the surface from about May to October) occurs in large areas of UK shelf seas, typically in depths exceeding about $50 \mathrm{~m}$; below, cold bottom water warms only slowly. The water column remains vertically mixed where the depth is relatively shallow and/or tidal currents are large. Salinity is influenced primarily by Atlantic water salinity, and locally by fresher-water inflows from rivers via estuaries; values are usually between 34 and adjacent upper oceanic values 35.3 to 35.6 (measured in parts per thousand); (sections 2, 4.2).

\section{ii. How has the assessment been undertaken?}

Variability and trends have been assessed on the basis of many time series spanning several decades. There is no clear reference point or criterion to assess status.

Data come from many sources: Volunteer Observing Ships, drifting and moored buoys, repeated sections, Bottom Trawl surveys, coastal stations, and satellite radiometers. Recent developments include: more profiling floats (the international Argo programme) providing data essential for yearround monitoring in deep waters west of the UK, RAPID monitoring the North Atlantic overturning circulation, FerryBox instrumentation on some ferries, (changed) support for some long-term series (western Channel, Isle of Man, Liverpool Bay) (section 2).

\section{iii. Current and likely future status of temperature and salinity}

- Global temperature trends are: warming over the past century; fastest warming of surface waters sea surface temperature (SST) warmed by about $0.3{ }^{\circ} \mathrm{C}$ from 1910 to 1940 , remained steady until the 1970s and has since continued to warm by about another $0.4^{\circ} \mathrm{C}$. Global and North Atlantic warming trends apply to Atlantic waters adjacent to the UK. The warming is especially evident near the surface and since the mid-1980s has been of the order of 0.5 to $1{ }^{\circ} \mathrm{C}$. However, a global and Atlantic decrease in salinity at UK latitudes is not seen in Atlantic waters adjacent to the UK; with salinity here increasing by 0.05 to 0.1 since the late 1970s 'Great Salinity Anomaly' minimum. On top of these overall trends is spatial and interannual-to-decadal variability of the order of 0.5 to $2{ }^{\circ} \mathrm{C}$ in temperature and 0.05 to 0.1 in salinity (sections $4.1,4.2$ ).

- Annual SST averaged around the UK coastline has increased by about 0.5 to $1{ }^{\circ} \mathrm{C}$ for the period 1871 to 2000. Much of the warming occurred in the period 1920 to 1940 and again since the mid1980s; the latter was common with UK shelf waters SST, being especially pronounced in the southern North Sea, Irish Sea and Tiree Passage (sections 4.2, 4.3).

- Salinity trends vary (tending to increase where influenced most by Atlantic water).

- Spatial and interannual temperature variability in UK waters is of the order of $0.5^{\circ} \mathrm{C}$; up to 2 to $3{ }^{\circ} \mathrm{C}$ in shallow areas for an extreme month. Winter temperatures tend to be warmer when westerly winds prevail. Likewise, shorter-term salinity variability exceeds the multi-decadal trend. Irish Sea salinities are especially variable; freshwater inputs are relatively important (section 4.3).

- In future, climate change may bring reduced flow of warm Atlantic water past the west of the UK. However, shelf-sea temperatures are likely to follow the atmospheric climate quite closely. Modelled future scenarios suggest most warming in the south and east, especially in autumn, and a general increase in the number of stratified days. Confidence in these predictions is low to moderate (section 5). 
- Future salinities over the shelf will reflect a combination of adjacent oceanic values (hitherto with small variability of the order of 0.1 ) and freshwater inputs: from rivers and net rainfall minus evaporation. Modelled future scenarios suggest lower salinity (by roughly 0.2) in UK waters at the end of the 21st century; confidence in this prediction is low (section 5).

\section{iv. What has driven change?}

Temperature and salinity changes in the Atlantic are controlled by the large-scale circulation coupled with atmospheric weather and climate. In shallower UK shelf seas, changes in local weather and climate (influenced by Atlantic waters) are the main factor affecting temperature; salinity is locally reduced by variable outflows from rivers.

\section{v. What are the uncertainties?}

Interannual variability exceeds longer-term trends over periods of decades, making trends difficult to determine. The spatial resolution of salinity measurements is sparse relative to local variations near river outflows. For the future, climate scenarios for temperature are uncertain, for rainfall even more uncertain; these uncertainties increase at the regional level.

\section{vi. Forward look}

Operational models assimilate regularly-measured data to provide day-to-day estimates of the ocean state and forecasts of its evolution. This entails maintaining the present intensity of measurements to constrain model forecasts close to 'truth'. Argo has proved particularly valuable below the surface of the deep ocean; there is no equivalent in UK shelf seas. There is scope for model experiments to estimate what density, frequency and allowable time-delay in observed data provide the best (cost/benefit) value for predictions, forecasts and state-estimation.

\section{Introduction}

Heat and salt in the seas are critical to climate; controlled by temperature and salinity differences, the seas store and transport large amounts of heat.

Globally, ocean temperatures vary from about $-2{ }^{\circ} \mathrm{C}$, in deep polar waters and where ice forms, to over $30^{\circ} \mathrm{C}$ in some tropical waters and marginal seas in hot arid regions (e.g. Red Sea, South Australian gulfs). Surface waters are generally warmer towards the tropics, and towards the western side of subtropical oceans as a result of circulation. In the North Atlantic, this is exemplified by the Gulf Stream from which warm surface waters extend north-eastwards, some eventually flowing past the UK to the Norwegian Sea (after cooling). Except in polar regions, surface waters are generally warmer than deep water below the main 'thermocline' (where the temperature changes rapidly with depth); the main thermocline is several hundred to a thousand metres deep in the NE Atlantic. In the sub-tropics and towards polar seas, the top $50 \mathrm{~m}$ or so, above a seasonal thermocline, are warmer in summer than water below; in autumn, surface cooling and mixing deepens the seasonal thermocline, usually down to the main thermocline by the end of winter. The Atlantic adjacent to the UK has typical temperatures as shown in Table 2.1.

In the shallower shelf seas around the UK, temperature changes near the deeper Atlantic can reflect the movement of Atlantic Water onto the shelf. This influence of Atlantic Water on temperature is greatest at the shelf edge and decreases onto the shelf. Some influence of Atlantic Water properties appears in MCCIP (2008) plots of temperature since 1970; the north-western North Sea (at the seabed), the core Atlantic Water at the western shelf edge of the Norwegian Trench, and the Fair Isle Current (between Orkney and Shetland) show similar variations on 5- to 10-year timescales.

For the majority of the north-west European shelf seas, not reached by Atlantic Water within a few months, the main factors controlling temperature are mixing (by currents) and weather: local and regional; solar heating and heat exchange with the atmosphere (Sharples et al., 2006). This is because the timescale for adjustment of temperature in $\mathrm{O}(100 \mathrm{~m})$ water to the atmosphere is a few months 
(only). Hence the Atlantic influence is primarily via the atmosphere (i.e. prevailing westerly winds). In winter, a positive North Atlantic Oscillation (NAO) Index (see chapter 1 Weather and Climate)

usually corresponds with higher air temperatures and stronger wind speeds, thereby affecting atmosphere-ocean heat exchange. Loewe (1996) found that the NAO Index accounts for $40 \%$ to $50 \%$ of the winter SST variability in the southern North Sea. Spring and summer heating causes water in the top 30 to $50 \mathrm{~m}$ to be warmer than below, unless tidal currents are strong enough to mix through the total depth all year (which typically occurs in depths of less than $50 \mathrm{~m}$ ). Typical shelf sea temperatures are as shown in Table 2.2.

Locally, cooling water from power stations may have a significant effect. A modern power station may discharge heat of order of $3 \mathrm{GW}$ in cooling water, comparable with solar heating over $10 \mathrm{~km}^{2}$. (The marine effect is minimized if the discharged water is hot, on the surface and losing heat rapidly to the atmosphere.)

Salinity may be defined as the mass of dissolved material per mass of seawater (solution), expressed in parts per thousand. According to depth, NE Atlantic salinities are typically in the range 34.9 to 36 (about 35.2 to 35.6 in upper waters adjacent to the UK). Individual water types may show changes of the order of 0.1 on time scales of years to decades. Values of the order of 35 (as distinct from 30 or 40) have been established on time scales of millennia and longer.

In UK shelf seas, salinities are typically 34 to 35, slightly less than in the adjacent Atlantic. Influences are the salinity of Atlantic Water (predominant; unlike temperature), exchanges of water with the atmosphere (slight) and freshwater from land and rivers (locally important). Areas on the continental shelf which are most influenced by inflowing oceanic waters were typically fresher in the mid- to late 1970s, related to the passage of the 'Great Salinity Anomaly'. The atmosphere is a net source of freshwater where rainfall exceeds evaporation; in fact over many UK shelf-sea areas rainfall minus evaporation is within $\pm 200 \mathrm{~mm} / \mathrm{y}$. Indeed, $\pm 200 \mathrm{~mm} / \mathrm{y}$ freshwater input (variability) corresponds to changes in salinity of less than $1 \%$ (0.3), if (as typically) the depth exceeds $20 \mathrm{~m}$ and water flows through in periods of a year or less. Inputs of freshwater from land and rivers are moderate in global terms, but exceed the net atmospheric input in most UK shelf-sea areas except to the west and north of Scotland (Regions 6 and 7; because most of Scotland drains eastwards; however, Regions 6 and 7 are affected by fresher water from the Clyde and Irish Sea - Region 5 - where river inputs are relatively important). Salinity near river outflows depends strongly on the mixing between river and sea water in estuaries, and on river flow strength. Outflow salinities are typically between 30 and 35, as most UK estuaries are well mixed and the volume change between high and low water is large relative to river flow during one tidal cycle. Salinities may be lower in a surface layer if mixing is weak (as favoured by small tidal range, neap tides, deep estuarine and coastal waters).

Changes in sea temperature cause sea level changes (q.v. topic chapter 5: Sea level); warming causes sea-level rise through thermal expansion.

Heat storage and transport in the ocean are important because the specific heat and density of water are large (relative to the atmosphere). Meridional (tropics to poles) transport of energy is required for the Earth system to be in global radiative balance; some $30 \%$ to $50 \%$ of this energy transport is via ocean currents at mid-latitudes and an even larger proportion at lower latitudes (Bryden and Imawaki, 2001). Ocean circulation (transporting heat) is determined primarily by forcing due to momentum, heat and water fluxes to and from the atmosphere; the distributions of temperature and salinity in the ocean establish its density structure and density differences drive currents. Mixing due to wind and tidal energy input also controls the density structure and enables meridional overturning circulation (e.g. warm poleward flow above deeper equatorward flow in the North Atlantic). The density structure also affects the smaller-scale dynamics of fronts and eddies - 'ocean weather' - which, together with the Antarctic Circumpolar Current and western boundary currents like the Gulf Stream, are the most energetic open-ocean flows. Near coasts, fresher waters from rivers often result in (1) estuarine circulation having net surface outflow and bottom inflow, (2) along-shore coastal currents, and (3) density stratification (which varies according to wind conditions) with fresher water on top (as it is less dense). Fresher water exiting the Irish Sea, and local river outflows, drive the Scottish Coastal Current northwards around western Scotland. 
Descriptions of monitoring networks that regularly measure sea temperature and salinity are given by the UK Directory of the Marine-observing Systems (www.ukdmos.org). These monitoring networks are extensive and include: Argo profiling floats; Volunteer Observing Ships (VOS); drifting and moored buoys which are the primary source of Hadley Centre SST data HadISST utilised here; sections (the 'extended Ellett line') across Rockall Trough and to Iceland; sections across the FaroeShetland Channel; Marine Automatic Weather Stations (MAWS, on moored buoys and lightships around the UK); several ferry routes; several locations of maintained offshore mooring locations and sections or grids surveyed on the continental shelf; many coastal time series. Ships can measure surface temperature and salinity while underway; satellite radiometers give a measure of sea-surface (skin) temperature. Stratification and bottom temperature and salinity are not so widely measured; although the annual ICES International Bottom Trawl Survey specifically measures bottom temperature and salinity.

Daily analyses of SSTs for the global ocean are produced by Operational Sea Surface Temperature and Sea Ice Analysis (OSTIA; Stark et al., 2007), with resolution 1/20 (approx. 5 km). OSTIA uses satellite data provided by the GHRSST project, together with in situ observations to determine SST. An example is given in Figure 2.1 showing seasonal distributions for the North Atlantic. Notable features are (1) cold surface waters extending from the Nordic Seas around Greenland to the Labrador Sea and US east coast, (2) warm water in the Gulf Stream and its extension across the North Atlantic to Iceland, UK and Norway, and (3) large seasonal range in the Baltic, Mediterranean and Black Seas. Figure 2.2 shows seasonality and some interannual variability in the spatially averaged SSTs shown in Figure 2.1.

Salinity and temperature play important roles in the functioning of marine ecosystems. Some examples follow. Stratification in the upper water column can be important to primary production; in some cases prompting a spring phytoplankton bloom. The salinity of water overlying the seabed affects nitrogen release from sediments and thus its availability for primary production. Many organisms or life stages are adapted to specific salinity ranges, especially in saline pools, lagoons and estuaries; salinity fluctuations can cause sub-lethal stress or even death. Sea temperature affects the geographic distribution of marine biota and can cause changes in biodiversity, with effects on species composition, reproduction, plankton and fish populations. Hátún et al. (2009) attributed biogeographical shifts in the NE Atlantic to exchanges of sub-arctic and sub-tropical water masses. Edwards et al. (2001) showed that there has been a steady increase in phytoplankton biomass in the North Sea since the mid-1980s; a peak in 1989 corresponded with anomalously warm SSTs.

Beaugrand et al. (2002) found rising sea temperatures to be a factor in the northward extension (by more than $10^{\circ}$ latitude) of warm-water copepods (small planktonic crustaceans). There has been a similar retreat of colder-water plankton to the north (a mean poleward movement of 200 to $250 \mathrm{~km}$ per decade (see HBDSEG chapters Plankton and Fish where such changes are discussed further).

\section{Progress since Charting Progress}

The IPCC Fourth Assessment Report (Meehl et al., 2007) reinforced the concept that global temperatures are rising with climate change.

In general, the array of temperature and salinity measurements around the UK has been maintained and in some respects enhanced. Changes in the array include:

- more Argo profiling floats (in deep oceans globally; specifically in the North Atlantic); these have greatly improved monitoring of temperature and salinity down to $1500 \mathrm{~m}$;

- RAPID monitoring of the North Atlantic Meridional Overturning Circulation;

- a few changes in the MAWS (Marine Automatic Weather Station) array;

- increased use of ferry routes with installation of FerryBox or similar equipment on ships;

- support for the Western Channel locations E1 and L4 as sustained observations;

- some changes in the arrangements for monitoring around the Isle of Man with closure of the Port Erin Marine Laboratory (the longest time series are continuing). Launch of NCOF (the National Centre for Ocean Forecasting) in 2005 formalised Met Office collaboration with the UK academic community; it allows efficient input of world-class science to operational marine model forecast 
products for UK waters and beyond (some products have been available for more than a decade). Important products from model forecasts include temperature and salinity through the water column, supplementing the measurements which are fewer at depth than near the surface.

\section{Presentation of the evidence}

\subsection{Global and North Atlantic sea temperature and salinity}

Globally, the ocean is warming as shown by the heat content having increased significantly since the late 1950s. All oceans, including the Atlantic, show a net warming (Levitus et al., 2000; Bindoff et al., 2007: fig. 5.1). More than half of the increase in heat content has occurred in the upper $300 \mathrm{~m}$ of the ocean, equivalent to a rate of warming of about $0.04{ }^{\circ} \mathrm{C}$ per decade (IPCC, 2001); in the upper $700 \mathrm{~m}$, the increase was about $0.1^{\circ} \mathrm{C}$ in the period 1961 to 2003 (Meehl et al., 2007). Global SSTs for the past 100 years show two distinct warming periods: the first from about 1910 to 1940 with a warming of about $0.3{ }^{\circ} \mathrm{C}$, and the second starting during the 1970 s with warming of another $0.4{ }^{\circ} \mathrm{C}$ (Trenberth and Jones et al., 2007: fig. 3.4). However, there is significant variability on decadal or shorter time scales (e.g. relative cooling in the mid-1980s and high values in the period 1997 to 1998). Thus the global trends, illustrated in Figure 2.3 comprise warming over the past century, additional variability on all time scales, and fastest warming of surface waters.

Ocean salinity is changing on gyre and basin scales (Bindoff et al., 2007). Where evaporation is fast, near-surface salinity is increasing in almost all ocean basins. At high latitudes, surface waters are freshening consistent with greater rain- or snowfall; more freshwater from land and rivers, ice melting, advection and changes in circulation may also contribute.

Atlantic salinity increased during the period 1955 to 1998 in the area defined by $15^{\circ}$ to $42^{\circ} \mathrm{N}$ but decreased in the area defined by $42^{\circ}$ to $72^{\circ} \mathrm{N}$ (Bindoff et al., 2007: Figures 5.5 to 5.7). These trends accord with the global trends (increasing salinity of more saline waters and freshening of less saline waters). However, the North Atlantic experienced further variability, with freshening during the Great Salinity Anomaly in the 1970s and a further minimum in the 1990s. Since the 1990s minimum, the upper ocean west and north of the UK is again more saline, reflecting the proportions of inflowing sub-tropical (saline) and sub-polar (fresher) water (Holliday, 2003a; Meehl et al., 2007; MCCIP, 2008; Ivchenko et al., 2009).

NE Atlantic temperature trends are compared with global trends in Figure 2.3; the region appears to have warmed relatively rapidly from an anomalously cool start in the period from 1993. (Here and in many places following, seasonality is 'removed'; an overall mean for each month is subtracted month by month from the time series to produce a monthly anomaly time series). North-Atlantic SST has risen faster than the global average over the past 25 years (and especially since 1993), perhaps due in part to the Atlantic Multi-decadal Oscillation (MCCIP, 2008): this is a natural mode of variability; North Atlantic SST is the dominant feature; successive peaks and troughs are at intervals of roughly 65 years (Knight et al., 2005). The greater variability in surface waters is to be expected (less thermal capacity in the 0 to $50 \mathrm{~m}$ depth range than in 0 to $300 \mathrm{~m}$ or deeper). Trends also vary spatially in the NE Atlantic.

With sufficient Argo tracked floats (from 2001), temperature in the NE Atlantic can be monitored to $1500 \mathrm{~m}$ depth; Figure 2.3 shows the correspondingly improved availability of data at depth. Ivchenko et al. $(2006,2009)$ analysed Argo temperature data to monitor changes in oceanic heat content in the North Atlantic as a function of depth and latitude band (Figures 2.4 and 2.5). Figure $2.4\left(40^{\circ}-50^{\circ} \mathrm{N}\right.$ and $50^{\circ}-60^{\circ} \mathrm{N}$ ) shows warming on which is superimposed 'quasi seasonal' variations. Figure 2.5 $\left(40^{\circ}-60^{\circ} \mathrm{N}, 0^{\circ}-30^{\circ} \mathrm{W}\right)$ shows warming overall but relative cooling from mid-2005 to the beginning of 2007 (the end of the analysis period); this may just be 'normal' interannual variability.

Operational analyses (and forecasts) of ocean temperature and salinity fields at $1^{\circ}$ (latitude by longitude) and $1 / 9^{\circ}$ resolution are produced routinely by the Met Office's Forecasting Ocean Atmosphere Model (FOAM; Martin et al., 2007). The analyses assimilate observed data; for subsurface structure the model relies heavily on the availability of Argo profiles. 
The temperature anomaly fields (Figure 2.6a) show cooling from 2005 to 2007 in some areas at all three levels in the NE Atlantic. The cooling is most pronounced at the $1000 \mathrm{~m}$ level (influenced by the Labrador Sea water mass) west of Ireland. This cooling pattern reinforces the findings from the Ivchenko et al. (2006) analysis and suggests that cooling from 2005 continued at least until early 2007. The corresponding salinity anomaly fields (Figure 2.6b) suggest freshening between 2005 and 2007, particularly marked in the north of the analysis area and at the deepest level, $1000 \mathrm{~m}$.

Despite 2005-2007 cooling, warming (since the mid-1980s and before) is found in all shelf-sea regions around the NE Atlantic (Hughes et al., 2008). Synthesis of the 30-year data set from the Ellett Line (Rockall Trough) with other sustained ocean observations from the North Atlantic and Nordic Seas shows the spread of warm water throughout the region. Time lags along the spreading pathway can be explained by the net advective speed of the Atlantic inflow; the time lag from the Ellett Line in the northeast subpolar gyre to Fram Strait is 3 to 4 years. The data show that interannual to decadal-scale patterns of variability have a large-scale coherence (Holliday et al., 2008). Warming since 1983, in the North Atlantic adjacent to the UK is also illustrated in Figures 2.7 (sub-surface) and 2.8 (SST), along with spatial variability in the trends.

The SST trends in Figure 2.8 may be compared with marine air temperature trends in Figure 2.9. There are broad similarities (overall positive, similar magnitudes, greater towards the west / westnorth-west and in the southern North Sea). A marine effect on westerly air flow is suggested by the eastward displacement of air temperature trend patterns (north of Scotland, German Bight) relative to the SST trend patterns.

Satellite data (Figures 2.10) confirm that SSTs in the North Atlantic adjacent to the UK were typically higher in the period 2003 to 2007 than the 1985-2001 average. They also show that spatial and interannual variability of the order of 1 to $2{ }^{\circ} \mathrm{C}$ is superimposed on any such trend.

Spatial variability of salinity is not available to match these maps of SST. However, long time-series of temperature and salinity are available in Rockall Trough and the Faroe-Shetland Channel for North Atlantic waters adjacent to the UK.

In Rockall Trough, Charting Progress (Defra et al., 2005) reported that temperatures were relatively low in the early 1990s but rose by the late 1990s to reach values similar to those in the 1960s.

Temperature in Rockall Trough has continued to rise (Figure 2.11a). After relatively low temperatures in the early 1990s (relatively lowest in May 1994), the average temperature of the top $800 \mathrm{~m}$ in Rockall Trough has risen continually since the mid-1990s. A dip in temperature in the period 2000 to 2001, as reported in Charting Progress, was followed by increases in the period 2003 to 2006. The temperature anomaly, calculated from the 1975-2000 long-term mean, peaked at $0.8{ }^{\circ} \mathrm{C}$ in 2008 . The persistently warm conditions are similar to those found in all regions around the NE Atlantic.

Rockall Trough salinity is shown in Figure $2.11 \mathrm{~b}$. Salinity of the top $800 \mathrm{~m}$ of the Ellett Line increased through the late 1990s and into the 2000s. After a dip in the period 2000 to 2001, salinity increased to a peak in 2003, with a salinity anomaly 0.08 above the 1975-2000 long-term mean. Since 2003 salinity has remained roughly constant. A slight dip during the period 2004 to 2006 results from fresher water on the west side of the section, between the Anton Dohrn Seamount and Rockall Bank $\left(11^{\circ}-13^{\circ} \mathrm{W}\right)$. The apparent overall increasing trend contrasts with decreasing salinity in the North Atlantic generally at this latitude (Bindoff et al., 2007). Holliday (2003b) attributed Rockall Trough salinity variations to varying amounts of relatively fresh North Atlantic Current water mixing with saline Eastern North Atlantic Water entering the southern Rockall Trough. Temperature continued to increase in the period 2003 to 2007 while salinity decreased, so the density of the upper layer decreased, giving greater stratification with possible implications for deep mixing, the overturning thermohaline circulation, upwelling of nutrients and biological production.

In the Faroe-Shetland Channel, surface waters have generally warmed over the past two decades, with highest temperatures in 2003 and a slight decrease to 2007 (Figure 2.12a). Faroe-Shetland Channel salinity (Figure 2.12b) shows interannual and some shorter-period variability, fluctuations on 
timescales of about five years and some overall decrease to a minimum in the late 1970s (the time of passage of the Great Salinity Anomaly) have since been followed by some increase. The magnitude of the shorter-period fluctuations ( five years or less) exceeds that of the longer-period changes over the duration of the 58-year time series. Since the reporting period of Charting Progress there was a maximum in 2003 followed by an overall decline $\sim 0.05$ to 2007, with superimposed fluctuations of the order of 0.05, but higher values again in 2008 and 2009.

Overall, it is concluded that global and North Atlantic warming trends, especially since the mid-1980s, apply to Atlantic waters adjacent to the UK. The warming is especially clear near the surface, of the order of 0.5 to $1{ }^{\circ} \mathrm{C}$ since the mid-1980s. However, the global and Atlantic decrease in salinity at UK latitudes (1955-1998; Bindoff et al., 2007) is not seen in Atlantic waters adjacent to the UK; indeed, salinity here has increased by 0.05 to 0.1 since the late 1970 s Great Salinity Anomaly minimum. On top of these overall trends is spatial and interannual-to-decadal variability of similar magnitude (i.e. of the order of 0.5 to $2{ }^{\circ} \mathrm{C}$ in temperature and 0.05 to 0.1 in salinity).

\subsection{UK waters sea temperature and salinity}

Section 2 outlines the control of shelf-sea temperature primarily by mixing and local weather, with some influence of Atlantic water near where it moves onto the shelf. Typical salinities of 34 to 35 , slightly less than in the adjacent Atlantic, are influenced primarily by Atlantic water salinity, slightly by exchanges of water with the atmosphere and significantly, locally, by freshwater from land and rivers (with values of 30 or less in estuaries).

SST for UK waters is shown as annual averages for the period 1870 to 2007 in Figure 2.13. There is interannual, decadal and longer-term variability. Most striking is the increase after 1987 (about 0.2 to $0.6{ }^{\circ} \mathrm{C}$ per decade) with sustained high values from 1997. This is supported by independent local time series shown later, and appears to be a coherent change in the North Sea, English Channel and Irish Sea. MCCIP (2008) reported that marine (air and) SST have been rising at a similar rate to land air temperature, but with strong regional variations. 2007 has been the warmest year in UK coastal waters (up to 2007) since records began in 1870; seven of the ten warmest years occurred in the decade to 2007.

The seasonal cycle of SST in UK waters (Figure 2.14) shows an average range of about $8{ }^{\circ} \mathrm{C}$ (latewinter minimum to late-summer maximum) and higher temperatures throughout the year in the period 1997 to 2007 relative to the period 1961 to 1990. Analyses by Evans et al. (2004) for UK coastal waters confirmed a rise in temperature over a 40-year period (1960s to 1990s); they also found (1) faster rises in mid-summer and mid-winter than at other times of year, and (2) an earlier rise in spring and an earlier autumn: a 2-week shift in (air and) sea temperatures.

Spatial variability in SST (seasonal cycle and annual mean) is illustrated by data from Met Office MAWS buoys and Light Vessels (www.ukdmos.org ). Figure 2.15 shows larger seasonal variation in shallow water, summer maxima decreasing from south to north, and interannual variability sufficient to obscure any trend in the period 2003 to 2008 (Figures 2.8 and 2.13 show trends on longer timescales).

Distributions of SST are shown with fine resolution by satellite remote sensing (e.g. Figures 2.1 and 2.10) and by operational numerical models.

Satellite remote sensing (Figure 2.10) shows almost all areas and years 2003 to 2007 as having positive annual SST anomalies relative to 1985-2001 climatology. 2003 and 2004 patterns are similar: raised SST $\left(+1\right.$ to $\left.2{ }^{\circ} \mathrm{C}\right)$ in the North Sea, Scottish Shelf and Atlantic NW Approaches; slightly raised SST $\left(<+0.5^{\circ} \mathrm{C}\right)$ in the English Channel and Irish Sea. August 2003 (Figure 2.16) was the time of the European summer heat-wave; temperatures in the North Sea were then $4{ }^{\circ} \mathrm{C}$ higher than the $1985-$ 2001 average. 2005 and 2006 (Figure 2.10) were cooler but still above average ( 0 to $+1^{\circ} \mathrm{C}$ ). In March 2006 parts of the English Channel were $3{ }^{\circ} \mathrm{C}$ lower than average (Figure 2.16, at the end of a winter with low NAO Index). September 2006 to May 2007 (spanning a winter with high NAO Index) were up to $2{ }^{\circ} \mathrm{C}$ higher than average for a majority of UK waters. 2007 (Figure 2.10) indicates a new pattern 
of raised SST ( 1 to $2{ }^{\circ} \mathrm{C}$ ) in the southern North Sea, Channel, Irish Sea and Atlantic NW Approaches, with less anomaly in the northern North Sea and Scottish Shelf. MCCIP (2008) reported likewise that warming has been faster in the English Channel and southern North Sea than within Scottish continental shelf waters. Overall, however, these figures emphasise spatial and temporal variability: interannual variability of the order of 1 to $2{ }^{\circ} \mathrm{C}$ and extremes of 2 to $3{ }^{\circ} \mathrm{C}$ in any one year.

Such variability is superimposed on mean seasonal temperature distributions illustrated by the Met Office NCOF's operational Atlantic Margin Model output (Figure 2.17). For a model description see Bell et al. (2000), Holt et al. (2003) and Stark et al. (2007). These modelled SSTs rise to the south; seasonal range increases to the east (more 'continental' climate) and in shallow waters such as the southern North Sea and eastern-most Irish Sea. Cool plumes suggest extra mixing in strong tidal currents around several headlands and for a limited distance south of Orkney and Shetland.

Corresponding surface salinities are shown in Figure 2.18. The general pattern is a reduction from open Atlantic salinities as coasts are approached; the most extensive reductions are in the southern and eastern North Sea (to about 34 typically) and in the Irish Sea extending northwards in the Scottish Coastal current (32 to 34). Salinities are as low as 30 along the continental coast from Belgium to Denmark, and in the Baltic outflow. Nevertheless, near-oceanic salinities are carried through the English Channel and into most of the North Sea. Seasonality is most marked off Norway (fresher in summer) and appears weak in UK waters.

\subsubsection{Stratification}

Surface and bottom temperature, and salinity, may differ (Figures 2.17 to 2.20). Each year, from about May to October, large areas of UK shelf seas stratify as surface waters are warmed. A sharp density interface is then maintained, by wind mixing from the surface and tidal mixing from the seabed upwards. Below the density interface, cold bottom water is left over from the previous winter; it warms only very slowly after the onset of stratification. However, the water column remains vertically mixed by tidal stirring all year where the water depth is relatively shallow (typically nearer to shore) and/or depth-averaged tidal currents are large (Simpson and Hunter, 1974). Where freshwater influence is significant, salinity may cause (possibly intermittent) stratification depending on levels of freshwater discharge. (A notable example of different of surface and bottom salinities occurs around Scandinavia).

Between stratified and mixed areas there is typically a sharp change of horizontal temperature (and/or salinity) with a horizontal scale $\mathrm{O}(10 \mathrm{~km})$. At such tidal mixing fronts (Hill et al., 2008) there is usually a surface front and a bottom front (as illustrated respectively in Figures 2.17 and 2.19). The bottom front usually shows the larger density gradient; bottom fronts can exist without a surface front being present. Tidal mixing fronts appear in Figure 2.19 (July) from Flamborough Head to northern Denmark, across the western end of the English Channel and Bristol Channel, around the western Irish Sea and between the inner and outer shelf areas west of Scotland.

Observed distributions of North Sea bottom temperature and salinity in winter (February) are provided annually by the ICES International Bottom Trawl Survey; Figures 2.21 and 2.22 show 1971-2000 averages. Temperature correlates inversely with water depth; winter cooling removes similar quantities of heat in different areas so that shallow waters cool most. (Cooler waters in the German Bight and off Denmark also reflect lower air temperatures in winter.) Bottom salinities show a balance between oceanic and local freshwater influences; the 1971-2000 averages are correlated with water depth, distance from the coast and proximity to inflow from the open Atlantic.

The overall 1971-2007 bottom temperature trend is for warming everywhere (Figure 2.23). Example time-series for particular locations are shown in Figure 2.25 and show much interannual variability, of the order of $3{ }^{\circ} \mathrm{C}$ or more in shallow water far from the moderating influence of Atlantic water. High values around 1990 coincide with positive NAO Index but subsequent low values have variable timing in the period 1994 to 1996. The more recent rise in temperature appears unrelated to the NAO although a correlation between NAO Index and late winter 2006 and 2007 temperature was previously noted (see section 4.2). 
The overall 1971-2007 trend in salinity (Figure 2.24) is unclear except for increasing salinity in the northern North Sea with most oceanic influence. Example time-series for particular locations are shown in Figure 2.25. The late 1970s dip associated with the Great Salinity Anomaly has decreasing influence as distance from the open ocean increases. The Great Salinity Anomaly coincided with low NAO Index. Some influence of the NAO on salinity may be expected via wind effects on inflows of Atlantic water to the shelf and via rainfall to freshwater inflows. However, since the Great Salinity Anomaly there has been little apparent correlation between salinity and NAO Index or between salinity time-series at the different locations (except Viking Bank and Fladden Ground). In all cases interannual variability ( 0.1 to 1 or more) is comparable with change due to any overall trend.

The distribution of total stratification by season (Figure 2.26; 1961-1990 average) was simulated with the Atlantic Margin Model (Holt et al., 2003). Tidal mixing fronts between summer-stratified and mixed waters are apparent, but are displaced slightly into mixed areas in comparison with the bottom fronts in Figure 2.19.

Simulated evolution through 2001 (from day 91) of surface-bed temperature difference over the continental shelf is shown in a video clip at UKMAR - OPEG - dtmp.HRCSrun017. The model is POLCOMS (3-D) with resolution $~ 1.8 \mathrm{~km}$ and 32 vertical 'levels' in $48^{\circ} \mathrm{N}-62^{\circ} \mathrm{N}, 12^{\circ} \mathrm{W}-13^{\circ} \mathrm{E}$ (Holt and Proctor, 2008).

Another view of summer stratification and tidal mixing fronts is provided by vertical sections across the shelf sea between mixed and stratified areas. Examples are shown in Figures 2.27 and 2.28. Nearsurface waters in the Celtic Sea (stations B7 to CS05) were up to $2{ }^{\circ} \mathrm{C}$ warmer than in the Irish Sea in July 2008 (Figure 2.27), although the isolated bottom water in the Celtic Sea (e.g. CS01) was colder than bottom water in the Irish Sea (e.g. S26). The seasonal thermocline varies spatially, probably linked to total water depth (J. Sharples, NOC, pers. comm., 2009) and to enhanced mixing by internal waves at the shelf edge (CSO6, CS07).

Irish Sea transects for August 2008 (Figure 2.28) show a typical summer situation; the water in Liverpool Bay (LBY01 and CEFAS M) is warm (because shallow) and fresh (through river inputs) relative to western Irish Sea waters. The outer region of Liverpool Bay and the eastern Irish Sea are usually vertically mixed; in contrast, the western Irish Sea is stratified largely due to the vertical gradients in temperature. The water beneath the stratified region is much colder. Some fresher water at the surface can also be seen near the Irish coast.

Variation in stratification through time at one location is illustrated in Figures 2.29 and 2.30. Data over 12 years (Figure 2.29) show that the onset of stratification varies (determined by local meteorological conditions), taking place sometime between April and May (e.g. Figure 2.30). (The start of phytoplankton production depends on the establishment of stratification.). In June and July, surface warming continues and the depth of the warmest surface water decreases. In August to October, the near-surface heat mixes downwards forming a deeper surface layer of warmer water; eventually the water is mixed throughout its depth. Such a cycle is typical of summer-stratified waters (exact timings vary interannually and with location).

Overall it is concluded that shelf-sea temperature is controlled primarily by mixing and local weather, with some influence of Atlantic water near where it moves onto the shelf. Salinities are influenced primarily by Atlantic water salinity, and locally by freshwater from land and rivers. Surface temperatures have risen, particularly since the mid-1980s, but salinity trends vary (tending to increase where influenced most by Atlantic water). Temperature has a strong seasonal cycle, larger in shallow water; summer maxima decrease from south to north. Interannual to decadal variability in salinity is as large as its multi-decadal trend, and in temperature is of the order of 1 to $2{ }^{\circ} \mathrm{C}$, with extremes of 2 to $3{ }^{\circ} \mathrm{C}$. Summer stratification (from about May to October) occurs in large areas of UK shelf seas as surface waters are warmed; below, cold bottom water warms only very slowly. The water column remains vertically mixed where the depth is relatively shallow and/or tidal currents are large.

\subsection{Time series at specific locations}


The following sections proceed clockwise around the UK (from north of Scotland) with time series from ferry routes, and from individual offshore and coastal locations supporting the overall conclusions in section 4.2. Locations are indicated in Figure 2.31.

Atlantic water, more than $10^{6} \mathrm{~m}^{3} / \mathrm{s}$ in total, enters the northern North Sea primarily via the Fair Isle current between Orkney and Shetland, around Shetland and southwards along the western slope of the Norwegian Trench. Overall salinity values (typically between 34 and 35.4 in the North Sea) are set by the inflowing Atlantic water. (The Norwegian Coastal Current outflow carries less saline surface water from the Baltic and Scandinavian fjords and rivers.) Water of Atlantic origin also penetrates into the southern North Sea through Dover Strait: the transport of about $10^{5} \mathrm{~m}^{3} / \mathrm{s}$ (Prandle et al., 1993, 1996) is important in raising southern North Sea salinity. The main input of freshwater into the North Sea is from rivers discharging along its southern seaboard and the Baltic, reducing salinity in the southern and eastern North Sea. Charting Progress shows time series of sea-surface salinity anomalies averaged over the northern North Sea from 1950 to 2002. Salinity is higher in winter; possible explanations are: (1) evaporation over the sea, greater in autumn-winter than in spring-summer (Dooley, H., pers. comm., ICES, 2003); (2) more wind-driven flow of higher-salinity Channel water through Dover Strait to the southern North Sea. There was no clear winter trend. In the summer time series, there was an apparent freshening in the late 1970s and early 1980s and incomplete recovery thereafter (to 2002).

Figure 2.32 shows that in the Fair Isle Current, temperature and salinity vary on seasonal, year-to-year and 5-10-year timescales. High salinities occurred in 2003; since the reporting in Charting Progress values fell until a sharp rise in 2007. Temperature shows a sharp rise in the period 1987 to 88 , a fall in 1992 to 1994, and then two sharp rises to a maximum in 2003. Comparisons of Fair Isle current temperature and salinity with Atlantic water north of Scotland are made in Figure 2.33. There is correlation on a 5-year timescale, and in the long-term trend of temperature, but interannual variability in the Fair Isle Current markedly exceeds that in the Atlantic water.

\subsubsection{Northern North Sea}

For Region 1 (Figure 2.31), coastal sea temperature and salinity are available from Stonehaven (Figure 2.34), and temperature from Scarborough (Figures 2.35a,b) and an offshore buoy in the Tyne/Tees area (Figure 2.36). The Stonehaven time series show some correspondence with the Fair Isle Current on an annual timescale (temperature has a seasonal cycle, salinity has a few months delay at times); salinity shows additional variability against which no trend is significant. The Scarborough temperature shows a marked dip and then rise in the late 1980s, a dip in the early 1990s to the 19712000 average and then a rise from 1994 to a sustained level nearly $1{ }^{\circ} \mathrm{C}$ above that average. Stonehaven and Scarborough show notable interannual variability. The 2006 and 2007 winters differ; the warmer (2007; also fresher at Stonehaven) coincided with strongly positive NAO Index. The 2007-2006 temperature difference, maximal in March (about $1.5^{\circ} \mathrm{C}$ for Scarborough), slowly decreases until a rapid reversal in July-August. Although only for two years, the Tyne/Tees temperature statistics illustrate interannual variability of the order of 2 to $3{ }^{\circ} \mathrm{C}$ in summer months and ranges of 5 to $6^{\circ} \mathrm{C}$ for surface temperature within any one summer month.

\subsubsection{Southern North Sea}

For Region 2 (Figure 2.31), annual temperature time series from 1880 at Humber and Newarp Light Vessels are shown in Charting Progress, albeit with gaps and ending in the 1980s. Interannual variability, typically 0.5 to $1{ }^{\circ} \mathrm{C}$ for annual means 8 to $10{ }^{\circ} \mathrm{C}$ and 8.5 to $10.5^{\circ} \mathrm{C}$ respectively, is greater than any overall trend over that whole period. Coastal sea temperatures are available from Spurn Point and Southwold (replacing Sizewell; Figures 2.37a,b and 2.38a,b), and from West Gabbard off Harwich (Figure 2.39) and surface temperature and salinity time-series are available near $52^{\circ} \mathrm{N}$ from the Harwich-Rotterdam ferry route at 'offshore' and 'coastal' locations (Figures 2.40a,b and 2.41a,b).

The Spurn Point, Southwold and both ferry time series show a dip and then a marked rise in the late 1980s, dips in the early 1990s and again in 1996 down to the 1971-2000 average; thereafter values 
fluctuate but average about $1{ }^{\circ} \mathrm{C}$ above the 1971-2000 mean. The 2006 and 2007 winter temperatures differ, the warmer (2007) coinciding with strongly positive NAO Index. The temperature difference is maximal in March: about $2{ }^{\circ} \mathrm{C}$ at West Gabbard and Southwold, greater than $3{ }^{\circ} \mathrm{C}$ in both ferry time series. There is reversal by June at Spurn Point and Southwold, by August at West Gabbard and by July at both ferry stations. 'Coastal' winter temperatures are lower than 'offshore' and the minimum is typically reached in February rather than March; both effects are attributable to shallower water (less thermal capacity) and are common with the coastal sites (Scarborough, Spurn Point, Southwold). Interannual variability for monthly values is of the order of $\pm 1^{\circ} \mathrm{C}$ and the range of temperature within any one month is up to $5^{\circ} \mathrm{C}$.

Salinity shows no clear long-term trend, whether 'offshore' (Figures 2.42a,b) or 'coastal' (Figures $2.43 a, b)$. After low values in 2001 (somewhat earlier at 'coastal'), salinity rose to near-average values through most of the period 2002 to 2007, with some short excursions to fresher values and a more marked drop in 2007. The average 'coastal' seasonal cycle shows a maximum in November and a minimum in May; the average 'offshore' cycle is about two months later (February maximum, JuneJuly minimum). However, 2006 and 2007 exemplify that individual years can be very different, almost month-by-month which suggests local freshwater influence. Figure 2.44 shows the mean annual cycle in a temperature-salinity diagram; lower-salinity summers and higher-salinity winters probably reflect changes in freshwater input from rivers and inflow of water from the English Channel to the southern North Sea.

\subsubsection{English Channel}

For Region 3 (Figure 2.31), coastal sea temperature is available from Dover, Eastbourne, Weymouth and Poole Bay (Figures 2.45, 2.46, 2.47 and 2.48). The Dover and Eastbourne time series show a marked dip and then rise in the late 1980s, a dip in the early 1990s to the 1971-2000 average but a rise thereafter to an average level nearly $1^{\circ} \mathrm{C}$ above the 1971-2000 average, albeit with large fluctuations. The 2006 and 2007 winter temperatures differ, the warmer (2007) coinciding with a strongly positive NAO Index. Whereas these coastal minima (in shallow water) are usually in February, satellite coverage suggests that SST is usually at a minimum in March, as were the coastal minima in 2006 with more cooling (negative NAO Index). The temperature difference between 2006 and 2007, maximal (nearly $4{ }^{\circ} \mathrm{C}$ ) in March, slowly decreases until a rapid reversal in June-July. The Weymouth record differs in several respects: less variability until the late 1980s with no dip in the mid-1980s; a stronger rising trend (especially in summer) from low temperatures in 1996; the 2007-2006 winter temperature difference peaked at about $3{ }^{\circ} \mathrm{C}$. For all the records, interannual variability for monthly values is of the order of $\pm 1{ }^{\circ} \mathrm{C}$ and the range of temperature within any one month is up to $5{ }^{\circ} \mathrm{C}$. All these aspects of behaviour are very similar to conditions in the southern North Sea (Region 2).

\subsubsection{Western Channel - ferry route}

For the Channel (Portsmouth to the south-west and beyond, Regions 3 and 4) temperature and salinity data are available from the Pride of Bilbao FerryBox (www.ukdmos.org ). Plots of weekly data (temperatures, Figures 2.49 to 2.53; salinities, Figures 2.54 to 2.57 ) are organised into two groups. The first group shows data on a grid of latitude and day of year (weekly resolution): (1) for each year $(2005,2006,2007),(2)$ the 2005-2007 mean, and (3) each year's difference from the mean. The second group shows time series of all available gridded data from 2003 to 2007 at selected latitudes: $50.5^{\circ} \mathrm{N}$ (UK coastal); $50.0^{\circ} \mathrm{N}$ (shallow well-mixed central English Channel with depths of 30 to $60 \mathrm{~m}$ ); $49.5^{\circ} \mathrm{N}$ (shallow summer stratifying western Channel).

The temperature and salinity fields indicate year to year variability (from 2003) rather than progressive change. In stratified waters at $49^{\circ} \mathrm{N}$ and $49.5^{\circ} \mathrm{N}$ a clear temperature peak occurred in 2006 . This would be consistent with a very calm period being followed by stormy weather. At these latitudes the hot weather of 2003 produced peak temperatures around week 27, before a period of bad weather in the English Channel. For waters on the shelf, 2006 waters were warmer later in the year; this carried over to warmer waters in the spring of 2007. This warmer water would have been enhanced by the fine stable weather of spring 2007. However, summer 2007 was the coldest recorded in all areas in this data set. 
The salinity data particularly show variability in the transport of freshwater from rivers on the French Atlantic coast. The strong intrusion seen in 2003 relative to 2004 was investigated by Kelly-Gerreyn et al. (2006). At the southern entrance to the western English Channel $\left(48.5^{\circ} \mathrm{N}, 5.1^{\circ} \mathrm{W}\right.$, near Ushant), low-salinity $(<35)$ surface waters (LSSW) were observed in late winter (March-April) in three successive years (2002-2004; Kelly-Gerreyn et al., 2006). Subsequently LSSW accumulation was weak in 2005, strong in 2006 and weak in 2007. By comparison with studies of data for French river discharges and measurements in French coastal waters (Puillat et al., 2004), the source of the LSSW was identified as northward-spreading plumes from the Loire and Gironde (French Biscay coast). Fastest plume travel-times were associated with north-easterly winds, consistent with Ekman theory. Differences between years in mean winter (January-March) combined river discharges (D) were consistent with the minimum salinities $\left(\mathrm{S}_{\min }\right)$ of the LSSW in successive years for the period 2002 to 2004:

$$
\begin{aligned}
& D=1579,3630,4211 \mathrm{~m}^{3} / \mathrm{s} \\
& S_{\text {min }}=34.53,33.90,33.68
\end{aligned}
$$

Winter-mean (1905-1974) salinity is otherwise 35.33 near Ushant.

Subsequent intrusion of the LSSW into the western English Channel is very variable from year to year. During the period 2003 to 2007, the low-salinity intrusion was freshest (mean $=35.11 \pm 0.21$ ) and most penetrative (reaching $50.7^{\circ} \mathrm{N}, 1.0^{\circ} \mathrm{W}$ by the end of the year) in 2003 and 2006. In 2003 and 2006 the progressive movement of the LSSW to the north and into the English Channel can be seen as a minimum-salinity feature in the time-series plots occurring at different times at different latitudes. Kelly-Gerreyn et al. (2006) considered that the strong 2003 intrusion resulted from the coincidence of high dispersion from spring tides and favourable winds (southwesterly / southeasterly) enhancing the longer term residual flow. They were unable to identify a link of the LSSW to phases of the winter NAO Index.

Overall these findings emphasise the dependence of surface temperatures on weather and salinities on the amount and transport of freshwater from rivers.

\subsubsection{Western Channel and Celtic Sea}

The western English Channel (Region 4) has stations E1 $\left(50^{\circ} 02^{\prime} \mathrm{N}, 4^{\circ} 22^{\prime} \mathrm{W}\right.$; water depth $75 \mathrm{~m}$; started by the Marine Biological Association in 1902) and L4 (50 $15^{\prime} \mathrm{N}, 4^{\circ} 13^{\prime} \mathrm{W} ; 50 \mathrm{~m}$; started by Plymouth Marine Laboratory in 1988; see www.ukdmos.org ). (A Celtic Sea transect is shown in section 4.2). E1 and L4 are strongly influenced by tides and weather. E1 is mainly influenced by North Atlantic water, and develops a summer thermocline: typically stratification starts in early April, persists throughout the summer and is eroded by the end of October. The typical depth of the summer thermocline is around $20 \mathrm{~m}$. The L4 time series is shorter and noisier, with coastal and river Tamar influence.

Figure 2.58 for E1 shows monthly temperature anomalies since 1903, at the surface and at $50 \mathrm{~m}$ depth. Recent values are warm, 1 to $2{ }^{\circ} \mathrm{C}$ above the long-term (1903-2007) average. The monthly plots show that on average the coolest temperature $\left(9{ }^{\circ} \mathrm{C}\right)$ is in March and the warmest $\left(16^{\circ} \mathrm{C}\right)$ is in August at the surface and in October $\left(14{ }^{\circ} \mathrm{C}\right)$ at the bottom. 2007 included the warmest February, March and autumn values ever recorded. The summer of 2007 was closer to average. This is apparent throughout the depth of the water column. Figure 2.59 for L4 shows more variability and the shorter duration makes any firm conclusions more difficult, although again February and autumn 2007 were warm.

Figure 2.60 shows the monthly salinity anomalies at E1 since 1903 . There is an average seasonal cycle with a maximum in February and minimum in August, possibly associated with more intense summer rainfall depressing the summer salinity values. However, interannual and shorter-term variability greatly exceed this average seasonal variation. There appears to be a maximum at about 35.5 related to salinity in the adjacent open Atlantic. Excursions to lower salinity can be greater. Interestingly, May 2007 was notably wet and the outcome in salinity is obvious. Other values in 2007 were typically 0.1 above long-term averages. Figure 2.61 for L4 shows more variability, even from week to week at the 
surface; bottom salinities are less variable than surface values. The shorter duration and variability at L4 make any firm conclusions difficult.

\subsubsection{Irish Sea}

Isle of Man Government Laboratory (IoMGL) measurements of temperature and salinity are available along $54^{\circ} \mathrm{N}$ (in collaboration with the UK Environment Agency), at Cypris and Port Erin Breakwater (data to 2006 were obtained by the Port Erin Marine Laboratory).

The $54{ }^{\circ} \mathrm{N}$ temperature series show summer stratification at sites A to $\mathrm{C}$ west of the Isle of Man (Figure 2.62). Sometimes there is stratification also at sites $\mathrm{G}$ to I to the east; this may be reinforced by salinity (Figure 2.64; e.g. site $\mathrm{G}$ in 1993, 1995) aided by freshwater input from several rivers (from North Wales round to Morecambe Bay). In winter there is little surface-bottom temperature difference (Figure 2.63); the majority of winter temperature differences have warmer water near the bed while the surface is fresher (for stability; e.g. site G in 2003, 2004; Figure 2.65).

Cypris and Port Erin (Figures 2.66; 2.67 and 2.69) show a rising trend in temperature, about $1{ }^{\circ} \mathrm{C}$ over the past 50 years; the best-fit curve at Cypris and the 5-year running mean at Port Erin both suggest a faster rise in the past 20 years. Nevertheless, year-to-year variability often exceeds $0.5^{\circ} \mathrm{C}$. On average the seasonal cycle at Port Erin has a minimum in March and a maximum in August. The difference between the years 2006 (negative NAO Index) and 2007 (positive NAO Index; Figure 2.68) is less than at coastal stations in the North Sea, English Channel or Liverpool Bay; it hardly varies from March to May but reverses by July.

The local sea-air differential has decreased significantly over the period 1948 to 2007 (Figure 2.70); local air temperature has increased faster than sea temperature. An inverse linear relationship exists between the NAO Index and the local sea-air temperature differential (e.g. for a positive NAO Index, prevalent westerlies tend to be associated with warmer air and less sea-air difference). Hisscott (2006) postulated that one possible consequence of this changing sea-air temperature difference is a change in the frequency of fog around the Isle of Man coast. The number of days with fog observed by the Met Office at Ronaldsway is closely correlated with the sea-air temperature difference. Fog in summer has become more frequent since the mid-1970s whereas fog in winter became less frequent during the period 1947 to 2004.

Liverpool Bay temperatures from a Cefas Smart Buoy (Figure 2.71) and Coastal Observatory mooring show: an average rise of $1.1^{\circ} \mathrm{C}$ between earlier measurements (1935-1961) and 2002-2007 (Figure 2.72); a marked contrast between the 2006 (cold) and 2007 (warm) winters (negative and positive NAO Index, respectively), as in the North Sea and Channel; this contrast almost disappears by June.

Overall salinity trends and curvature at Cypris and Port Erin (Figures 2.73 and 2.74) are small relative to interannual variability. In Liverpool Bay, salinity in the period 2002 to 2007 shows no clear change from a 1935-1961 average (Figure 2.72). Cypris salinity is somewhat correlated inversely with the NAO Index (Figure 2.75), possibly via less freshwater input in negative-NAO Index winters. There is also much variability on shorter time scales, reflecting short-term freshwater inputs. Variability and reduced salinity in Liverpool Bay show the influence of river inflows, which are greater in winter than summer on average.

\subsubsection{West Scotland}

Data For West Scotland come from a long-term mooring in Tiree Passage (Region 6). The water column here is well mixed or weakly stratified throughout the year, except for occasional episodes: intrusions of high salinity water from the shelf break are sometimes apparent, mainly confined to the west of Tiree Passage. Over the full time series the mean water temperature was $10.1{ }^{\circ} \mathrm{C}$, and the dominant mode of variance in the temperature record was the seasonal cycle $(93.5 \%$ of the total variance), with an amplitude of $3.2^{\circ} \mathrm{C}$ (Figures 2.76 and 2.77). In contrast, seasonality of salinity is weak (amplitude 0.11, Figure 2.77), with a weak maximum in March and minimum in September. 
The temperature anomaly series (after subtracting the series-average seasonal cycle; Figure 2.78) shows a cooling from 1981 to the mid-1980s, maxima in the late 1980s and mid- to late 1990s with a minimum in the early 1990s. These anomalies are similar to (1) those for the full NE Atlantic upper layer (Holliday, 2003a) with highs in the late 1980s and late 1990s, lows in the early 1980s and mid1990s; (2) North Sea and Channel series in sections 4.3.2 and 4.3.3. The data for 2002 onwards show relative warmth, peaking in September 2006 at $1.76{ }^{\circ} \mathrm{C}$ above the long-term monthly mean for September. The overall trend (1981-2008) is warming at a rate of $+0.54{ }^{\circ} \mathrm{C}$ per decade. However, the error bounds on the linear trend (Figure 2.78) show that the simple linear model is a poor predictor of interannual change; additional interannual variability is of the order of $\pm 1^{\circ} \mathrm{C}$.

Interannual monthly-averaged salinity variability is large compared with the seasonal signal. Variability peaks in October and is least in May (Figure 2.77). The distribution is skewed by some particularly fresh months. From a peak value of 35.17 in January 2005 salinity in the Tiree Passage decreased to a record minimum of 32.80 in November 2006, and then rose to a record peak of 35.36 in March 2008, near to the limit set by Atlantic water salinity and 1.04 above the long-term mean of 34.32 (Figure 2.76).

\section{What the new evidence tells about environmental status}

The evidence shows global and North Atlantic warming trends, especially since the mid-1980s, likewise in Atlantic waters adjacent to the UK. Near-surface warming is of the order of 0.5 to $1{ }^{\circ} \mathrm{C}$ since the mid-1980s. Salinity in Atlantic waters adjacent to the UK has increased by 0.05 to 0.1 since a late 1970s minimum, contrary to global trends at UK latitudes. On top of these overall trends is spatial and interannual-to-decadal variability of similar magnitude (of the order of 0.5 to $2{ }^{\circ} \mathrm{C}$ in temperature and 0.05 to 0.1 in salinity). Against the overall trends, Argo and FOAM analyses appear to indicate a recent cooling and freshening in deep-water areas west of the UK since mid-2005. The causes and physical and biogeochemical implications of this are as yet unknown. (It may just exemplify interannual variability. Holliday (2003b) previously attributed varying Rockall Trough salinity to varying proportions of waters arriving from the south (more saline) and the west (fresher)). These conditions are important in controlling shelf-edge flows, exchanges between shelf and deep-sea waters and hence UK shelf-seas' salinity and flushing.

Despite this recent cooling, conditions in all regions around the NE Atlantic are warm in comparison with the mid-1980s and before (Hughes et al, 2008).

In shelf-sea areas, the main controls on the temperature are the local atmospheric conditions (over the past few months), the depth (h) of water and tidal-current strength $(\mathrm{U})$ in combination (larger $\mathrm{h} / \mathrm{U}^{3}$ gives summer stratification). Thus the trend to warmer waters has been sustained, albeit many locations had a maximum in the exceptional summer of 2003. March 2007 was relatively warm following a strongly positive winter NAO Index (an indicator of warm air and westerly winds). Shelfsea salinities are generally controlled overall by values (typically 35.2 to 35.6 ) in the adjacent open ocean; salinity in most shelf areas exceeds 34 most of the time. Salinities are decreased by net freshwater inputs from the atmosphere (slightly) and from rivers and estuaries (locally). The latter are important around many coasts, especially in the Irish Sea and southern North Sea. For example, the inverse correlation of Irish Sea salinity with NAO Index may relate to less freshwater input in negative-NAO Index winters; short-term Irish Sea salinity variability reflects freshwater inputs. River inputs are localised and occur over short time scales (weeks to months); the associated variability can dominate any seasonal cycle or longer-term variability.

Salinity's natural spatial and temporal variability on a range of time scales obscures any potential trend. Hence it is difficult to establish representative 'indicator' values for salinity.

For the future, MCCIP (2008) reported climate models indicating that SST will continue rising in all UK coastal waters, with stronger warming in the south-east $\left(\sim 0.15\right.$ to $0.4{ }^{\circ} \mathrm{C}$ per decade in the southern North Sea) than in the north-west $\left(\sim 0.05\right.$ to $0.2{ }^{\circ} \mathrm{C}$ per decade at Rockall). These predictions accord with the expectation that shelf-sea temperatures are likely to follow the atmospheric climate quite closely. There is a risk that climate change will be associated with a slowing of the Atlantic 
Meridional Overturning Circulation; this directly affects the volume of warm Atlantic water passing to the west of the UK, and to a limited extent the water on the adjacent UK shelf; elsewhere the effects will be more indirect via the effect on the atmospheric climate. There are modelled future seasonal scenarios, for example for the period 2070 to 2098 as illustrated for surface temperature (Figure 2.79), a measure of stratification (Figure 2.80) and timing of the start and end of seasonal stratification (Figure 2.81). These results are for the Atlantic Margin Model (Holt et al., 2003) forced by the atmosphere of HadRCM (a fine-resolution nesting of the European region in HadCM3) for the 'unperturbed' member of the UKCP ensemble with the medium IPCC emissions scenario SRES A1B. The projections show: most warming in the south and east, especially in autumn; a slight increase of intensity (but not area) of summer stratification over the (stratified areas of) shelf; a much larger increase in deeper-water stratification (and in the Norwegian Coastal Current); and a general increase in the number of stratified days, again more in autumn than spring, but with considerable local variability.

Future shelf-sea salinities are likely to follow adjacent oceanic values on annual to decadal timescales across the shelf as a whole. However, these changes have hitherto been of the order of 0.1 , smaller than shorter-term variability associated with freshwater inputs to shelf seas. This is exemplified by the variability in the Fair Isle current considerably exceeding that in the adjacent Atlantic water. Shelf-sea salinities will also be affected by climate change; possibly reduced if freshwater inputs from rivers and net rainfall minus evaporation increase (Figure 2.82). Such factors are taken into account in modelled future scenarios, for example for the period 2070 to 2098 as illustrated in Figure 2.82 (forced by an average outer-boundary salinity in HadRCM). These plots generally show a slight freshening of the order of 0.2 in UK waters, a result of a less saline boundary and more freshwater input (especially rainfall).

However, there is less confidence in regional climate-change projections than in global projections, and less confidence for the hydrological cycle (for salinity) than for temperature.

The summary table (Table 2.3) includes an assessment of trend but not status ('traffic-light') because (1) no accepted criteria apply for temperatures giving significant risk of adverse effects; and (2) the UK (government), or even the EU, cannot itself take measures to improve the status.

Temperature has risen overall since pre-industrial times by $\mathrm{O}\left({ }^{\circ} \mathrm{C}\right)$ with some differences between regions, but the differences are not enough to distinguish different levels of risk. The seasonal range is much greater than this change; interannual variability is somewhat greater. Rising temperature effects appear to include northward migration of plankton species with possible impacts at higher trophic levels. Larger and faster increases in future are likely and will make adaptation (natural or managed) more difficult. Salinity is subject to natural variability in relation to circulation and freshwater inputs. There is no reason to suppose that this variability or absolute values of salinity have changed enough to have had an impact on the environment or human health. The range of salinity values is very limited, except nearshore or in estuaries. There is little basis to distinguish between CP2 Regions.

\section{Forward look and need for further work}

Operational models assimilate regularly-measured data to provide day-to-day estimates of the ocean state and forecasts of its evolution. These data can include Argo and satellite imagery.

The Argo project now provides the means to monitor temperature and salinity (and velocity) in the open Atlantic adjacent to the Western European continental shelf. Argo measurements are confined to deep-water areas and thus are capable of providing only indications of conditions offshore of the UK and West European continental shelf. Nevertheless, these data have documented warming and a salinity increase since a 1990s minimum (as have ICES sections; Holliday et al., 2008). The analyses show the power of Argo data when coupled with state-of-the art assimilating models to reveal property trends and their spatial structure. The availability of Argo profile data for areas adjacent to the UK and NW Europe should be maintained so that the utility of the new analyses produced using Argo data can be evaluated. This requires continuation of the UK, other European and international partners' contributions to the Argo array. 
Routine monitoring of the ocean areas between the deep sea and the continental shelf poses logistical problems: Argo floats are limited to off-shelf areas (typically > $2000 \mathrm{~m}$ ); moored instruments are at risk from fishing activities; and ship coverage is relatively sparse. In parallel with Argo's development, similar sensors have been deployed on autonomous underwater gliders (Merckelbach et al., 2007). One such glider, operated by the National Oceanography Centre, has collected temperature and salinity data over the continental shelf and slope off West Africa

(www.noc.soton.ac.uk/omf/lmm/glider/data.php). There is clear potential for such instruments to be deployed to monitor key locations around the edge of the NW European shelf; future sustained measurements of properties in shelf seas (especially where summer-stratified) and across the continental slope using autonomous ocean gliders should be considered. For forecast purposes, these data need to be transmitted in near-real time.

Satellite imagery for surface temperature has the potential to provide spatial coverage to keep model forecasts 'on track'. There is no comparable regular estimate of sub-surface temperatures from observations. Satellite imagery has yet to be proven for inferring salinity; all sources of salinity data are sparse for the purpose of constraining model forecasts. There is scope for model experiments to estimate what density, frequency and allowable time-delay in data provide the best (cost/benefit) value for predictions, forecasts and subsequent state-estimation.

Operational systems are being developed in some shelf-sea areas. Temperature is the most routine of all their measurements, and salinity is relatively routine. Nevertheless, costs are relatively high for salinity and sub-surface temperature estimates. Dependence on models (constrained by available data) appears probable in the foreseeable future for reasonably detailed estimates in time and spatially. Salinity is more difficult to model than temperature; models depend on estimates of freshwater inputs which are localized and not fully estimated.

\section{References}

Beaugrand, G., Reid, P.C., Ibañez, F., Lindley, J.A. and Edwards, M., 2002. Reorganization of North Atlantic marine copepod biodiversity and climate. Science 296, 1692-1694.

Bell, M.J., Forbes, R.M. and Hines, A., 2000. Assessment of the FOAM global data assimilation system for real-time operational ocean forecasting. J. Mar. Syst. 25, 1-22.

Berry, D.I. and Kent, E.C., 2009. A new air-sea interaction gridded dataset from ICOADS with uncertainty estimates. B. Am. Meteorol. Soc.,90, 645-656.

Bindoff, N.L., Willebrand, J., Artale, V., Cazenave, A., Gregory, J., Gulev, S., Hanawa, K., Le Quéré, C., Levitus, S., Nojiri, Y., Shum, C.K., Talley, L.D. and Unnikrishnan, A., 2007. Observations: oceanic climate change and sea level. In: Climate Change 2007: The Physical Science Basis. Contribution of Working Group 1 to the Fourth Assessment Report of the Intergovernmental Panel on Climate Change. Edited by Solomon, S., Qin, D., Manning, M. Chen, Z., Marquis, M., Averyt, K.B., Tignor M. and Miller, H.L. Cambridge University Press. pp. 385-432.

Bryden, H.L. and Imawaki, S., 2001. Ocean heat transport. In: Ocean Circulation and Climate: Observing and Modelling the Global Ocean. Edited by Siedler, G., Church, J. and Gould, J. Academic Press. pp 455-474.

Defra, 2005. 2: Marine Process and Climate. IACMST contribution to Charting Progress - an Integrated Assessment of the State of UK Seas.

Edwards, M., Reid, P.C. and Planque, B., 2001. Long-term and regional variability of phytoplankton biomass in the Northeast Atlantic (1960-1995). ICES J. Mar. Sci. 58, 39-49. 
Evans, G.L., Williams, P.J. le B. and Mitchelson-Jacob, E.G., 2004. Analysis of secular changes in seawater temperature at coastal stations around England and Wales. (Abstract). In: Proc. Challenger Conference: Marine Science 2004, Liverpool.

Hátún, H., Payne, M.R., Beaugrand, G., Reid, P.C., Sandø, A.B., Drange, H., Hansen, B., Jacobsen, J.A. and Bloch, D., 2009. Large bio-geographical shifts in the north-eastern Atlantic Ocean: From the subpolar gyre, via plankton, to blue whiting and pilot whales. Progr. Oceanogr. 80, 149-162.

Hill, A.E., Brown, J., Fernand, L., Holt, J., Horsburgh, K.J., Proctor, R., Raine, R. and Turrell, W.R., 2008. Thermohaline circulation of shallow tidal seas. Geophys. Res. Lett. 35, L11605, doi:

10.1029/2008GL033459.

Hisscott, A., 2006. Trends in seasonal occasions of fog at Ronaldsway, Isle of Man. Weather 61, 202205.

Holliday, N.P., 2003a. Extremes of temperature and salinity during the 1990s in the northern Rockall Trough: results from the 'Ellett line'. ICES Mar. Sci. Symp. 219, 95-101.

Holliday, N.P., 2003b. Air-sea interaction and circulation changes in the northeast Atlantic. J. Geophys. Res. 108(C8), 3259, doi:10.1029/2002JC001344.

Holliday, N.P., Hughes, S.L., Bacon, S., Beszczynska-Moeller, A., Hansen, B., Lavin, A., Loeng, H., Mork, K.A., Osterhus, S., Sherwin, T. and Walczowski, W., 2008. Reversal of the 1960s - 1990s freshening trend in the northeast North Atlantic and Nordic Seas. Geophys. Res. Lett. 35, L03614, doi:10.1029/2007GL032675.

Holt, J.T. and Proctor, R., 2008. The seasonal circulation and volume transport on the northwest European continental shelf: A fine-resolution model study. J. Geophys. Res. 113, C06021, 20pp, doi:10.1029/2006JC004034.

Holt, M., Li, Z. and Osborne, J., 2003. Real time forecast modeling for the NW European Shelf Seas. In: Building the European Capacity in Operational Oceanography. Edited by Dahlin, H., Flemming, N.C., Nittis, K. and Petersson, S.E. Proceedings of the Third International Conference on EuroGOOS. Elsevier Oceanography Series 69, 484-489.

Hughes, S.L., Holliday, N.P. and Beszczynska-Möller, A. (Eds.), 2008. ICES Report on Ocean Climate 2007. ICES Coop. Res. Rep. 291, 64pp.

IPCC, 2001. Climate Change 2001: The scientific basis. Edited by Houghton, J.T., Ding, Y., Griggs, D.J., Noguer, M., van der Linden, P.J. and Xiaosu, D. Cambridge University Press.

Ivchenko, V.O., Wells, N.C. and Aleynik, D.L., 2006. Anomaly of heat content in the northern Atlantic in the last 7 years: Is the ocean warming or cooling? Geophys. Res. Lett. 33, L22606, doi:10.1029/2006GL027691.

Ivchenko, V.O., Wells, N.C., Aleynik, D.L. and Shaw, A.G.P., 2009. Variability of heat and salinity content in the North Atlantic in the last decade. Ocean Sci. Discuss. 6, 1971-2003.

Kelly-Gerreyn, B.A., Hydes, D.J., Jegou, A.M., Lazure, P., Fernand, L.J., Puillat, I. and Garcia-Soto, C., 2006. Low salinity intrusions in the western English Channel. Cont. Shelf Res. 26, 1241-1257.

Knight, J.R., Allan, R.J., Folland, C.K., Vellinga, M. and Mann, M.E., 2005. A signature of persistent natural thermohaline circulation cycles in observed climate. Geophys. Res. Lett. 32, L20708, doi:10.1029/2005GL024233. 
Loewe, P., 1996. Surface temperatures of the North Sea in 1996. Deutsche Hydrographische Zeitschrift 48, 175-184.

Martin, A.J., Hines, A. and Bell, M.J., 2007. Data assimilation in the FOAM operational short-range ocean forecasting system: A description of the scheme and its impact. Q. J. Roy. Meteorol. Soc. 133, 981-995.

MCCIP, 2008. Annual Report Card 2007-2008. Edited by Baxter J.M., Buckley P.J. and Wallace C.J. Marine Climate Change Impacts Partnership, Lowestoft, 8pp. More detail at: www.mccip.org.uk/arc/2007/Temperature.htm.

Meehl, G.A., Stocker, T.F., Collins, W., Friedlingstein, P., Gaye, A., Gregory, J., Kitoh, A., Knutti, R., Murphy, J., Noda, A., Raper, S., Watterson, I., Weaver, A. and Zhao, Z.C., 2007. Global climate projections. In: Climate Change 2007: The Physical Science Basis. Contribution of Working Group 1 to the Fourth Assessment Report of the Intergovernmental Panel on Climate Change. Edited by Solomon, S., Qin, D., Manning, M. Chen, Z., Marquis, M., Averyt, K.B., Tignor M. and Miller, H.L. Cambridge University Press, pp. 747-845.

Merckelbach, L.M., Smeed, D.A. and Testor, P., 2007. Observing deep ocean convection with gliders. Geophys. Res. Abstr. 9, 05482.

Palmer, M.D., Haines, K., Tett, S.F.B. and Ansell, T.J., 2007. Isolating the signal of global warming. Geophys. Res. Lett. 34, L23610, doi:10.1029/2007GL031712.

Prandle, D., Loch, S.G. and Player, R., 1993. Tidal flow through the Straits of Dover. J. Phys. Oceanogr. 23, 23-37.

Prandle, D., Ballard, G., Flatt, D., Harrison, A.J., Jones, S.E., Knight, P.J., Loch, S., McManus, J., Player, R. and Tappin, A., 1996. Combining modelling and monitoring to determine fluxes of water, dissolved particulate metals through the Dover Strait. Cont. Shelf Res. 16, 237-257.

Puillat, I., Lazure, P., Jegou, A.M., Lampert, L. and Miller, P.I., 2004. Hydrographical variability on the French continental shelf in the Bay of Biscay, during the 1990s. Cont. Shelf Res.24, 1143-1163.

Rayner, N.A., Parker, D.E., Horton, E.B., Folland, C.K., Alexander, L.V., Rowell, D.P., Kent, E.C. and Kaplan, A., 2003. Global analyses of sea surface temperature, sea ice, and night marine air temperature since the late nineteenth century. J. Geophys. Res. 108, D14, 4407, doi:10.1029/2002JD002670.

Sharples, J., Ross, O.N., Scott, B.E., Greenstreet, S.P.R. and Fraser, H., 2006. Inter-annual variability in the timing of stratification and the spring bloom in the north-western North Sea. Cont. Shelf Res. $26,733-751$.

Simpson, J.H. and Hunter, J.R., 1974. Fronts in the Irish Sea. Nature 250, 404-406.

Stark, J.D., Donlon, C.J., Martin, M.J. and McCulloch, M.E., 2007. OSTIA: An operational, high resolution, real time, global sea surface temperature analysis system. Oceans '07 IEEE Aberdeen, conference proceedings. Marine challenges: coastline to deep sea.

Trenberth, K.E., Jones, P.D., Ambenje, P., Bojariu, R., Easterling, D., Tank, A.K., Parker, D., Rahimzadeh, F., Renwick, J.A., Rusticucci, M., Soden, B. and Zhai, P., 2007. Observations: surface and atmospheric climate change. Chapter 3. In: Climate Change 2007: The Physical Science Basis. Contribution of Working Group 1 to the Fourth Assessment Report of the Intergovernmental Panel on Climate Change. Edited by Solomon, S., Qin, D., Manning, M. Chen, Z., Marquis, M., Averyt, K.B., Tignor M. and Miller, H.L. Cambridge University Press. pp. 235-336. 


\section{Figure captions}

Figure 2.1: Surface temperatures from the OSTIA analysis for January, April, July and October 2007. (C) Crown Copyright 2007, published by the Met Office.

Figure 2.2: The spatially averaged surface temperature for the North Atlantic region (as given by the region shown in Figure 2.1). Courtesy of the Met Office.

Figure 2.3: Sub-surface ocean temperature time series. The plots show anomalies averaged over the globe (black) and the North-East Atlantic $\left(44^{\circ} \mathrm{N}-66^{\circ} \mathrm{N}, 30^{\circ} \mathrm{W}-10^{\circ} \mathrm{E}\right.$; grey), and between the surface and 50, 300, 700 and $1500 \mathrm{~m}$. The ocean profiles were initially averaged onto a $2^{\circ}$ by $2^{\circ}$ lat/long grid and anomalies were derived by subtracting a climatology calculated from the data for 1956-2004. Time series points are plotted only in months when at least $10 \%$ of the ocean grid cells were sampled. The data source was the EN3 dataset (available from www.metoffice.gov.uk/hadobs), while processing followed the methodology of Palmer et al. (2007). Courtesy of the Met Office.

Figures 2.4: Changes in heat content in the upper $1500 \mathrm{~m}$ of the water column, for the full-width of the North Atlantic at (a) $40^{\circ}-50^{\circ} \mathrm{N}$ and (b) $50^{\circ}-60^{\circ} \mathrm{N}$. The plots show monthly (blue), 7-point filter (red) and 5-month moving averages (smoother blue). Year numbers indicate the start of each year. The temperature rises suggested by the linear fits are about $0.2^{\circ} \mathrm{C}$. Courtesy of V. Ivchenko, NOC.

Figure 2.5: Changes in heat content in the upper $1500 \mathrm{~m}$ of the water column in the North-East Atlantic for the region defined by $40-60^{\circ} \mathrm{N}, 0-30^{\circ} \mathrm{W}$. Year numbers indicate the start of each year. The plot shows the monthly (blue), 7-point filter (red) and 5-month moving average (green). The temperature rise suggested by the linear fit is about $0.13{ }^{\circ} \mathrm{C}$. After Ivchenko et al. (2006). Courtesy of V. Ivchenko, NOC.

Figures 2.6: Temperature and salinity anomaly fields (departures from the Levitus climatology), $40^{\circ}-$ $60^{\circ} \mathrm{N}, 30^{\circ} \mathrm{W}-0^{\circ} \mathrm{E}$, January 2005 and January 2007 . Winter dates were chosen to ensure that near surface fields were meaningful and unaffected by seasonal stratification. $1^{\circ}$ resolution output is shown. Gaps are due to intersection of the analysis level with bottom topography. Courtesy of the Met Office.

Figure 2.7: Sub-surface ocean temperature. Linear trends $\left({ }^{\circ} \mathrm{C} /\right.$ decade) in annual UK/North Atlantic anomalies for 1983-2006 averaged between the surface and (a) $300 \mathrm{~m}$ and (b) $700 \mathrm{~m}$ depth. The ocean profiles were initially averaged onto a $1.25^{\circ}$ by $1.25^{\circ}$ lat/long grid and anomalies were derived by subtracting a climatology calculated from the data for 1983-2006. Trends are plotted only where at least $50 \%$ of the years were sampled. The data source was the EN3 dataset (available from www.metoffice.gov.uk/hadobs), while processing followed the methodology of Palmer et al. (2007). Courtesy of the Met Office.

Figure 2.8: Sea surface temperature. Linear trends $\left({ }^{\circ} \mathrm{C} / \mathrm{decade}\right)$ in annual UK/North Atlantic anomalies for 1983-2007. The SST analysis is on a $1^{\circ}$ by $1^{\circ}$ lat/long grid and anomalies were derived by subtracting a climatology for 1961-1990. The data source was the HadISST1 dataset (available from www.metoffice.gov.uk/hadobs). Courtesy of the Met Office.

Figure 2.9: Air temperature. Linear trend in air temperatures estimated over the period 1982-2007 $\left({ }^{\circ} \mathrm{C} /\right.$ decade) from the NOC (Berry and Kent, 2009) air temperature analysis. Contours are r-squared values and show where there is confidence in the trends. Courtesy of NOC.

Figure 2.10. Annual-average SST anomaly from Earth Observation data, 2003-2007, from the mean of monthly anomalies relative to the 1985-2001 climatology; from the NOAA Pathfinder v5 dataset. Courtesy of P. Miller, Plymouth Marine Laboratory (PML).

Figure 2.11: Annual-mean temperature and salinity in Rockall Trough within the upper 0 to $800 \mathrm{~m}$, with a 3-point running mean overlaid. Courtesy of J. Read and N.P. Holliday, NOC. 
Figure 2.12: Temperature and salinity anomaly in the Atlantic Water forming the slope current along the Faroe-Shetland Channel. Courtesy of S. Hughes, Marine Scotland.

Figure 2.13: Annual-average SSTs for UK Territorial Waters for the period 1870-2007, from HadISST (Rayner et al. 2003). Blue bars show deviations of the annual average from the 1961-1990 average. The red line shows annual averages after smoothing with a 21-point binomial filter. Courtesy of the Met Office.

Figure 2.14: Seasonal cycle of monthly-average SSTs in UK waters for $2007\left({ }^{\circ} \mathrm{C}\right.$, green). The blue shaded area shows the range of monthly-average SSTs from the 1961-1990 period (the coldest January in $1961-1990$ was about $7.5^{\circ} \mathrm{C}$, the warmest was about $9.5^{\circ} \mathrm{C}$ ). The red shaded area shows the range of monthly-average SSTs for the 1997-2007 period (the coldest January was about $8.8^{\circ} \mathrm{C}$, the warmest was about $10^{\circ} \mathrm{C}$ ). Data from HadISST (Rayner et al., 2003). Courtesy of the Met Office.

Figure 2.15: SST data from the Met Office Marine Automated Weather Stations. The data are quality controlled and filtered using a running/boxcar 30-day mean. (a) K4, at $55^{\circ} 24 \square \mathrm{N}, 12^{\circ} 12 \square \mathrm{W}$; (b) $\mathrm{K} 7$, at $60^{\circ} 36 \square \mathrm{N}, 4^{\circ} 54 \square \mathrm{W}$; (c) Aberporth, at $52^{\circ} 24 \square \mathrm{N}, 4^{\circ} 42 \square \mathrm{W}$; (d) Seven Stones Light Vessel at $50^{\circ} 06 \square \mathrm{N}, 6^{\circ} 06 \square \mathrm{W}$; and (e) Sandettie at $51^{\circ} 06 \square \mathrm{N}, 1^{\circ} 48 \square$ E. Courtesy of the Met Office.

Figure 2.16: SST anomaly maps for the month of each year between 2003 and 2007 having the maximum positive anomaly (relative to 1985-2001), as well as March 2006 which had the greatest negative anomaly in the period 2003 to 2007. Courtesy of P. Miller, PML.

Figure 2.17: SSTs for January, April, July and October. A mean is shown for the month and the five years 2003 to 2007. Values are from the POLCOMSV6.3 Atlantic Margin Model (Holt et al., 2003; run in hindcast prior to March 2007, and then within the operational system in near-real time). Courtesy of the Met Office.

Figure 2.18: Surface salinities for January, April, July and October. A mean is shown for the month and the five years 2003 to 2007. Values are from the POLCOMSV6.3 Atlantic Margin Model (Holt et al., 2003; run in hindcast prior to March 2007, and then within the operational system in near-real time). Courtesy of the Met Office.

Figure 2.19: Seabed temperatures for January, April, July and October. A mean is shown for the month and the five years 2003 to 2007. Values are from the POLCOMSV6.3 Atlantic Margin Model (Holt et al., 2003; run in hindcast prior to March 2007, and then within the operational system in nearreal time). Seabed temperatures highlight the general decrease in temperature with depth, especially at the edge of shallower shelf seas. Courtesy of the Met Office.

Figure 2.20: Seabed salinities for January, April, July and October. A mean is shown for the month and the five years 2003 to 2007. Values are from the POLCOMSV6.3 Atlantic Margin Model (Holt et al., 2003; run in hindcast prior to March 2007, and then within the operational system in near-real time). Courtesy of the Met Office.

Figure 2.21: Average winter bottom temperatures calculated from the ICES International Bottom Trawl Survey Quarter 1 data for 1971-2000. Average values were calculated for data in each ICES statistical rectangle where there were more than 25 years of data. Courtesy of S. Hughes, Marine Scotland.

Figure 2.22: Average winter bottom salinities calculated from the ICES International Bottom Trawl Survey Quarter 1 data for 1971-2000. Average values were calculated for data in each ICES statistical rectangle where there were more than 25 years of data. The colour scale has a cut-off of 34.5; average salinity in coastal regions can be as low as 30.2. Courtesy of S. Hughes, Marine Scotland.

Figure 2.23 (left): Linear trend in winter bottom temperature $\left({ }^{\circ} \mathrm{C}\right.$ per decade) from the ICES International Bottom Trawl Survey Quarter 1 data for 1971-2007. Values were calculated from linear 
fit to data in ICES rectangles with more than 30 years of data. Data were rejected if the root-meansquared error exceeded 0.25. Courtesy of S. Hughes, Marine Scotland.

Figure 2.24 (right): Linear trend in winter bottom salinity (per decade) from the ICES International Bottom Trawl Survey Quarter 1 data for 1971-2007. Values were calculated from linear fit to data in ICES rectangles with more than 30 years of data. Large interannual variability in coastal regions makes a salinity trend difficult to determine with confidence; data were rejected if the root-meansquared-error exceeded 0.25. Courtesy of S. Hughes, Marine Scotland.

Figure 2.25: Winter bottom temperature (left) and salinity (right) from the ICES International Bottom Trawl Survey at selected North Sea fishing grounds. The thin black line shows the North Atlantic Oscillation (NAO) Winter Index. The linear trend since 1970 is shown (thicker black line). Courtesy of S. Hughes, Marine Scotland.

Figure 2.26: Distribution of total stratification in the North-East Atlantic by season, from the POLCOMSV6.3 Atlantic Margin Model (Holt et al., 2003). (The figure actually shows total potential energy anomaly: PEA proportional to [height $x$ density relative to depth-mean] totalled through depth). Courtesy of J. Holt, NOC.

Figure 2.27: Distribution of temperature and salinity in the upper $65 \mathrm{~m}$ of the Celtic and Irish Seas in July 2008 (stations as indicated on map). Courtesy of R. Gowen, Agri-Food and Biosciences Institute (AFBINI).

Figure 2.28: Temperature and salinity section across the Irish Sea in August 2008 (stations as indicated on map). Courtesy of R. Gowen, AFBINI.

Figure 2.29: Time series showing seasonal cycles of mean daily near-surface (2 m) and bottom (90 m) temperature in the western Irish Sea, at stations 45 and 38a (see Figure 2.28), using thermistors attached to an instrumented mooring. Courtesy of R. Gowen, AFBINI.

Figure 2.30: Evolution of thermal stratification in the western Irish Sea during 2002. Pale blue: coldest. Courtesy of R. Gowen, AFBINI.

Figure 2.31: Location of CP2 Regions and time-series measurements discussed in section 4.3. FIC Fair Isle current; St - Stonehaven; T/T - Tyne/Tees; Sc - Scarborough; Sp - Spurn Point; Sw Southwold; WG - West Gabbard; FC, FO - (Harwich-Rotterdam) Ferry Coastal, Ferry Offshore; Do Dover; Ea - Eastbourne; PB - Poole Bay; We - Weymouth, Cy - Cypris; PE - Port Erin; MB, Lpl Mersey Bar and Liverpool Bay; TP - Tiree Passage.

Figure 2.32: Fair Isle Current water temperature and salinity anomalies. Nominal position: $59^{\circ} 17 \square \mathrm{N}$, $2^{\circ} 10 \square$ W. Courtesy of S. Hughes, Marine Scotland.

Figure 2.33: Temperature and salinity anomalies (smoothed and seasonal cycle removed) showing a comparison between the Fair Isle inflow to the North Sea (blue line) and Atlantic water north of Scotland (red line). Courtesy of S. Hughes, Marine Scotland.

Figure 2.34: Weekly depth-averaged sea temperature and salinity at Stonehaven (green line) from 1997 to the end of 2007. Data from offshore sites in the North Sea and North Atlantic are also included (Blue - Fair Isle Current, North Sea; Red - North Atlantic water north of Scotland). Courtesy of S. Hughes, Marine Scotland.

Figure 2.35a: Sea temperature time-series for 1970 to 2007 at Scarborough. Respective panels show the monthly mean, the monthly anomaly relative to the 1971--2000 average, and the winter and summer anomalies. Courtesy of S. Dye, Cefas. 
Figure 2.35b: Sea temperature seasonal cycle at Scarborough for the period 1971 to 2000. The plot shows the average \pm 1 standard deviation and the monthly mean values for two contrasting NAO years: 2006 (negative NAO Index) and 2007 (positive NAO Index). Courtesy of S. Dye, Cefas.

Figure 2.36: Upper - sea temperatures by month at Tyne/Tees, $54^{\circ} 55^{\prime} \mathrm{N}, 0^{\circ} 45^{\prime} \mathrm{W}$, for 2007 and 2008 . The plots shows means (colour), maxima and minima (bars). Lower - exceedances emphasising winter and summer variations. Courtesy of J. Rees, Cefas.

Figure 2.37a: Sea temperature time-series for 1970 to 2007 at Spurn Point. Respective panels show the monthly mean, the monthly anomaly relative to the 1971-2000 average, and the winter and summer anomalies. Courtesy of S. Dye, Cefas.

Figure 2.37b: Sea temperature seasonal cycle at Spurn Point for the period 1971 to 2000. The plot shows the average \pm 1 standard deviation and monthly mean values for two contrasting NAO years: 2006 (negative NAO Index) and 2007 (positive NAO Index). Courtesy of S. Dye, Cefas.

Figure 2.38a: Sea temperature time-series for 1970 to 2007 at Southwold. Respective panels show the monthly mean, the monthly anomaly relative to the 1971-2000 average, and the winter and summer anomalies. Courtesy of S. Dye, Cefas.

Figure 2.38b: Sea temperature seasonal cycle at Southwold for the period 1971 to 2000. The plot shows the average \pm 1 standard deviation and the monthly mean values for two contrasting NAO years: 2006 (negative NAO Index) and 2007 (positive NAO Index). Courtesy of S. Dye, Cefas.

Figure 2.39: Upper - sea temperatures by month at West Gabbard (Harwich) for 2003 to 2008. The plot shows means (colour), maxima and minima (bars). Lower - exceedances emphasising winter and summer variations. Courtesy of J. Rees, Cefas.

Figure 2.40a: SST offshore time-series for 1970 to 2007 from the Harwich-Rotterdam ferry. Respective panels show the monthly mean, the monthly anomaly relative to the 1971-2000 average, and the winter and summer anomalies. Courtesy of S. Dye, Cefas.

Figure 2.40b: SST offshore seasonal cycle from the Harwich-Rotterdam ferry for the period 1971 to 2000. The plot shows the average \pm 1 standard deviation and the monthly mean values for two contrasting NAO years: 2006 (negative NAO Index) and 2007 (positive NAO Index). Courtesy of S. Dye, Cefas.

Figure 2.41a: SST coastal time-series for 1970 to 2007 from the Harwich-Rotterdam ferry. Respective panels show the monthly mean, the monthly anomaly relative to the 1971-2000 average, and the winter and summer anomalies. Courtesy of S. Dye, Cefas.

Figure 2.41b: SST coastal seasonal cycle from the Harwich-Rotterdam ferry for the period 1971 to 2000. The plot shows the average \pm 1 standard deviation and the monthly mean values for two contrasting NAO years: 2006 (negative NAO Index) and 2007 (positive NAO Index). Courtesy of S. Dye, Cefas.

Figure 2.42a: Surface salinity offshore time-series for 1970 to 2007 from the Harwich-Rotterdam ferry. Respective panels show the monthly mean, the monthly anomaly relative to the 1971-2000 average, and the winter and summer anomalies. Courtesy of S. Dye, Cefas.

Figure 2.42b: Surface salinity offshore seasonal cycle from the Harwich-Rotterdam ferry for the period 1971 to 2000 . The plot shows the average \pm 1 standard deviation and monthly mean values for two contrasting NAO years: 2006 (negative NAO Index) and 2007 (positive NAO Index). Courtesy of S. Dye, Cefas. 
Figure 2.43a: Surface salinity coastal time-series for 1970 to 2007 from the Harwich-Rotterdam ferry. Respective panels show the monthly mean, the monthly anomaly relative to the 1971-2000 average, and the winter and summer anomalies. Courtesy of S. Dye, Cefas.

Figure 2.43b: Surface salinity coastal seasonal cycle from the Harwich-Rotterdam ferry for the period 1971 to 2000 . The plot shows the average \pm 1 standard deviation and monthly mean values for two contrasting NAO years: 2006 (negative NAO Index) and 2007 (positive NAO Index). Courtesy of S. Dye, Cefas.

Figure 2.44: Temperature-Salinity plot showing 1971-2000 averages for each month at a 'coastal' (red) and 'offshore' (blue) site on the Harwich-Rotterdam ferry route. Courtesy of S. Dye, Cefas.

Figure 2.45a: Sea temperature time-series for 1970 to 2007 at Dover. Respective panels show the monthly mean, the monthly anomaly relative to the 1971-2000 average, and the winter and summer anomalies. Courtesy of S. Dye, Cefas.

Figure 2.45b: Sea temperature seasonal cycle at Dover for the period 1971 to 2000 . The plot shows the average \pm 1 standard deviation and the monthly mean values for two contrasting NAO years: 2006 (negative NAO Index) and 2007 (positive NAO Index). Courtesy of S. Dye, Cefas.

Figure 2.46a: Sea temperature time-series for 1970 to 2007 at Eastbourne. Respective panels show the monthly mean, the monthly anomaly relative to the 1971-2000 average, and the winter and summer anomalies. Courtesy of S. Dye, Cefas.

Figure 2.46b: Sea temperature seasonal cycle at Eastbourne for the period 1971 to 2000. The plot shows the average \pm 1 standard deviation and monthly mean values for two contrasting NAO years: 2006 (negative NAO Index) and 2007 (positive NAO Index). Courtesy of S. Dye, Cefas.

Figure 2.47a: Sea temperature time-series for 1970 to 2007 at Weymouth. Respective panels show the monthly mean, the monthly anomaly relative to the 1971-2000 average, and the winter and summer anomalies. Courtesy of S. Dye, Cefas.

Figure 2.47b: Sea temperature seasonal cycle at Weymouth for the period 1971 to 2000. The plot shows the average \pm 1 standard deviation and monthly mean values for two contrasting NAO years: 2006 (negative NAO Index) and 2007 (positive NAO Index). Courtesy of S. Dye, Cefas.

Figure 2.48: Upper - sea temperatures by month at Poole Bay for the years 2005 to 2008. The plots shows means (colour), maxima and minima (bars). Lower - exceedances emphasising winter and summer variations. Courtesy of J. Rees, Cefas.

Figure 2.49: Bilbao to Portsmouth. Weekly temperature data gridded by latitude for the years 2005 to 2007. Data from MiniPack CTD-F. Courtesy of D. Hydes, NOC.

Figure 2.50: Bilbao to Portsmouth. Mean weekly temperature data gridded by latitude for the period 2005 to 2007. Data from MiniPack CTD-F. Courtesy of D. Hydes, NOC.

Figure 2.51: Bilbao to Portsmouth. Difference in each year's weekly temperature data from the mean value for 2005-2007. Data from MiniPack CTD-F. Courtesy of D. Hydes, NOC.

Figure 2.52: Pride of Bilbao FerryBox time-series for seawater temperature the period 2003 to 2007. Data from MiniPack CTD-F. Courtesy of D. Hydes, NOC.

Figure 2.53: Pride of Bilbao FerryBox time-series for seawater temperature for the period 2003 to 2007. Data from a hull mounted SBE 48. Courtesy of D. Hydes, NOC.

Figure 2.54: Bilbao to Portsmouth. Weekly salinity data gridded by latitude for the years 2005 to 2007 . Data from MiniPack CTD-F. Courtesy of D. Hydes, NOC. 
Figure 2.55: Bilbao to Portsmouth. Mean weekly salinity data gridded by latitude for the period 2005 to 2007. Data from MiniPack CTD-F. Courtesy of D. Hydes, NOC.

Figure 2.56: Bilbao to Portsmouth. Difference in each year's weekly salinity data from the mean value for 2005 to 2007. Data from MiniPack CTD-F. Courtesy of D. Hydes, NOC.

Figure 2.57: Pride of Bilbao FerryBox time-series for salinity for the period 2003 to 2007. Courtesy of D. Hydes, NOC.

Figure 2.58: The left panels show temperature anomalies for surface water and at $50 \mathrm{~m}$ (equivalent to bottom temperature) at station E1 of the Marine Biological Association between 1903 and 2007. The right panels show monthly-average temperatures for surface water and at $50 \mathrm{~m}$. The solid line represents the average for all years of data, the dotted lines are the maximum and minimum for all years, and asterisks show 2007 data. Courtesy of T. Smyth, PML.

Figure 2.59: The left panels show temperature anomalies for surface water and at $50 \mathrm{~m}$ (equivalent to bottom temperature) at station L4 between 1993 and 2007. The right panels show monthly-average temperatures for surface water and at $50 \mathrm{~m}$. The solid line represents the average for all years of data, the dotted lines are the maximum and minimum for all years, and asterisks show weekly 2007 data. Courtesy of T. Smyth, PML.

Figure 2.60: The left panels show salinity anomalies for surface water and at $50 \mathrm{~m}$ (equivalent to bottom salinity) at station E1 of the Marine Biological Association between 1903 and 2007. The right panels show monthly-average salinities for surface water and at $50 \mathrm{~m}$. The solid line represents the average for all years of data, the dotted lines are the maximum and minimum for all years, and asterisks show 2007 data. Courtesy of T. Smyth, PML.

Figure 2.61: The left panels show salinity anomalies for surface water and at $50 \mathrm{~m}$ (equivalent to bottom salinity) at station L4 between 2002 and 2007. The right panels show monthly-average salinities for surface water and at $50 \mathrm{~m}$. The solid line represents the average for all years of data, the dotted lines are the maximum and minimum for all years, and asterisks show weekly 2007 data. Courtesy of T. Smyth, PML.

Figure 2.62: Summer temperature (end-June / beginning-July) along $54^{\circ}$ N. Courtesy of T. Shammon, IoM Government.

Figure 2.63: Winter temperature (end-January / beginning-February) along $54^{\circ} \mathrm{N}$. Courtesy of T. Shammon, IoM Government.

Figure 2.64: Summer salinity (end-June / beginning-July once each year) along $54^{\circ}$ N. Courtesy of T. Shammon, IoM Government.

Figure 2.65: Winter salinity (end-January / beginning-February once each year) along $54^{\circ} \mathrm{N}$. Courtesy of T. Shammon, IoM Government.

Figure 2.66: Sea temperature at Cypris $\left(54^{\circ} 05.50^{\prime} \mathrm{N}, 04^{\circ} 50.00^{\prime} \mathrm{W}\right), 1954$ to 2008 . The long-term trend is based on a second-order polynomial. Port Erin Marine Laboratory data to 2006. Courtesy of T.

Shammon, IoM Government.

Figure 2.67 Anomalies of annual mean SST at Port Erin and the 5-year running mean. Anomalies are relative to the 100-year mean, 1904 to 2003. Port Erin Marine Laboratory data to 2006. Courtesy of T. Shammon, IoM Government.

Figure 2.68: Monthly average SSTs at Port Erin (Isle of Man). The plot shows the 100-year mean, the maxima and minima and two contrasting NAO years: 2006 (negative NAO Index) and 2007 (positive NAO Index). Port Erin Marine Laboratory data to 2006. Courtesy of T. Shammon, IoM Government. 
Figure 2.69: Annual mean SSTs at Port Erin and annual mean air temperatures at Ronaldsway Meteorological Office, Isle of Man. Port Erin Marine Laboratory data to 2006. Courtesy of T. Shammon, IoM Government.

Figure 2.70: Annual mean sea-air differentials on the Isle of Man (SSTs at Port Erin minus air temperatures at Ronaldsway Meteorological Office). The plot shows the long-term trend based on the second order polynomial. Courtesy of T. Shammon, IoM Government.

Figure 2.71: Upper - sea temperatures by month at Liverpool Bay for the years 2003 to 2008. The plot shows means (colour), maxima and minima (bars). Lower - exceedances emphasising winter and summer variations. Courtesy of J. Rees, Cefas.

Figure 2.72: Monthly mean SSTs $\left({ }^{\circ} \mathrm{C}\right.$, left) and salinities (right) at Mersey Bar. The red line represents the average for the period 1935 to 1961, and the blue line the average for 2002 to 2007. Courtesy of J. Howarth, NOC.

Figure 2.73: Salinity at Cypris $\left(54^{\circ} 05.50^{\prime} \mathrm{N}, 04^{\circ} 50.00^{\prime} \mathrm{W}\right)$ from 1954 to 2008 . The second-order polynomial gives the overall trend and curvature. Courtesy of T. Shammon, IoM Government.

Figure 2.74: Anomalies of annual mean salinity at Port Erin and the 5-year running mean. Anomalies are relative to the mean for the period 1966 to 2005. Courtesy of T. Shammon, IoM Government.

Figure 2.75: Combined plot of the NAO Index and salinity at Cypris (note inverted scale). Courtesy of T. Shammon, IoM Government.

Figure 2.76: Measured hourly and monthly averaged temperature (left) and salinity (right) in Tiree Passage. Courtesy of M. Inall, SAMS.

Figure 2.77: Mean monthly temperature (left), salinity (right), \pm 1 standard deviation and the minimum and maximum monthly values for the Tiree Passage time series (temperature 1981-2008; salinity 2002-2008). Courtesy of M. Inall, SAMS.

Figure 2.78: Monthly mean temperature at Tiree Passage as an anomaly relative to the mean temperature for each month of the year. Error estimates of one standard deviation are shown. Courtesy of M. Inall, SAMS

Figure 2.79: Distribution of SST by season, modelled for 1961-1990 and 2070-2098 (Atlantic Margin Model, HadRCM, SRES A1B). Note the altered scale in the four plots showing the difference between the Past (1961-1990) and the Future (2070-2098). Courtesy of S. Wakelin, NOC.

Figure 2.80: Distribution of total stratification by season, for 1961-1990 and 2070-2098 from the POLCOMSV6.3 Atlantic Margin Model (Holt et al., 2003). (The figure actually shows total potential energy anomaly: PEA proportional to [height $\times$ density relative to depth-mean] totalled through depth). Note the altered scale for the difference between the Past (1961-1990) and the Future (2070 2098). Courtesy of J. Holt, NOC.

Figure 2.81: Distribution of average start and end days for seasonal stratification, modelled for 19611990 and 2070-2098 (Atlantic Margin Model, HadRCM, SRES A1B). Note the altered scale for the difference between the Past (1961-1990) and the Future (2070-2098). Courtesy of S. Wakelin, NOC.

Figure 2.82: Distribution of surface salinity by season, modelled for 1961-1990 and 2070-2098 (Atlantic Margin Model, HadRCM, SRES A1B). Note the altered scale for the difference between the Past (1961-1990) and the Future (2070-2098). Courtesy of S. Wakelin, NOC. 
Table 2.1 Typical temperatures $\left({ }^{\circ} \mathrm{C}\right)$ of Atlantic Ocean waters near the UK.

\begin{tabular}{|l|l|l|l|l|}
\hline Depth, m & SW of UK, winter & SW of UK, summer & NW of UK, winter & NW of UK, summer \\
\hline $0-50$ & $10-12$ & $16-18$ & $9-10$ & $12-14$ \\
\hline $200-500$ & $10-12$ & $10-12$ & $9-10$ & $9-10$ \\
\hline 2000 & $3-4$ & $3-4$ & $3-4(<0$ in Nordic $)$ & $3-4(<0$ in Nordic $)$ \\
\hline
\end{tabular}

Table 2.2 Typical temperatures $\left({ }^{\circ} \mathrm{C}\right)$ of UK shelf seas.

\begin{tabular}{|l|l|l|l|l|l|l|}
\hline & $\begin{array}{l}\text { Celtic Sea } \\
\text { winter }\end{array}$ & $\begin{array}{l}\text { Celtic Sea } \\
\text { summer }\end{array}$ & $\begin{array}{l}\text { S. North Sea } \\
\text { winter }\end{array}$ & $\begin{array}{l}\text { S. North Sea } \\
\text { summer }\end{array}$ & $\begin{array}{l}\text { N. North Sea } \\
\text { winter }\end{array}$ & $\begin{array}{l}\text { N. North Sea } \\
\text { summer }\end{array}$ \\
\hline Surface & $9-11$ & $16-18$ & $4-8$ & $16-19$ & $6-9$ & $12-14$ \\
\hline Bottom & $9-11$ & $10-14$ & $4-8$ & $16-19$ & $6-9$ & $6-10$ \\
\hline
\end{tabular}

Table 2.3 Summary assessment of trends.

\begin{tabular}{|c|c|c|c|c|c|c|}
\hline Parameter & $\begin{array}{l}\text { CP2 } \\
\text { Region }\end{array}$ & Key factors and pressure & $\begin{array}{l}\text { What the } \\
\text { evidence } \\
\text { shows }\end{array}$ & Trend & $\begin{array}{l}\text { Confidence } \\
\text { in } \\
\text { assessment }\end{array}$ & $\begin{array}{l}\text { Forward } \\
\text { look }\end{array}$ \\
\hline $\begin{array}{l}\text { Sea } \\
\text { Temperature }\end{array}$ & $\begin{array}{l}1,2,3, \\
5\end{array}$ & $\begin{array}{l}\text { Climate change. Affects } \\
\text { primary production, } \\
\text { species composition }\end{array}$ & $\begin{array}{l}\text { Rise in last } 25 \\
\text { years. } \\
\text { NAO winter } \\
\text { influence }\end{array}$ & Rising & High & $\begin{array}{l}\text { Continued } \\
\text { rise }\end{array}$ \\
\hline $\begin{array}{l}\text { Sea } \\
\text { Temperature }\end{array}$ & 4,6 & $\begin{array}{l}\text { Climate change. Affects } \\
\text { primary production, } \\
\text { species composition }\end{array}$ & $\begin{array}{l}\text { Rise in last } 25 \\
\text { years }\end{array}$ & Rising & High & $\begin{array}{l}\text { Continued } \\
\text { rise }\end{array}$ \\
\hline $\begin{array}{l}\text { Sea } \\
\text { Temperature }\end{array}$ & 7,8 & $\begin{array}{l}\text { Climate change, North } \\
\text { Atlantic source waters. } \\
\text { Affects primary } \\
\text { production, species } \\
\text { composition }\end{array}$ & $\begin{array}{l}\text { Rise from } \\
1994 \text { in } \\
\text { Rockall } \\
\text { Trough }\end{array}$ & Variable & Medium & Rise \\
\hline Salinity & 1 & $\begin{array}{l}\text { Circulation; river flows. } \\
\text { Can affect stratification, } \\
\text { nutrients, hence blooms }\end{array}$ & $\begin{array}{l}\text { Short-term } \\
\text { variability }\end{array}$ & $\begin{array}{l}\text { Possibly } \\
\text { increasing }\end{array}$ & High & $\begin{array}{l}\text { Lower } \\
\text { values? } \\
\text { (Low) }\end{array}$ \\
\hline Salinity & 2 & $\begin{array}{l}\text { Circulation; river flows. } \\
\text { Can affect stratification, } \\
\text { nutrients, hence blooms }\end{array}$ & $\begin{array}{l}\text { Short-term } \\
\text { variability }\end{array}$ & $\begin{array}{l}\text { Possibly } \\
\text { decreasing }\end{array}$ & High & $\begin{array}{l}\text { Lower } \\
\text { values? } \\
\text { (Low) }\end{array}$ \\
\hline Salinity & $\begin{array}{l}3,4,5 \\
6\end{array}$ & $\begin{array}{l}\text { Circulation; river flows. } \\
\text { Can affect stratification, } \\
\text { nutrients, hence blooms }\end{array}$ & $\begin{array}{l}\text { Short-term } \\
\text { variability }\end{array}$ & $\begin{array}{l}\text { Not } \\
\text { determined }\end{array}$ & High & $\begin{array}{l}\text { Lower } \\
\text { values? } \\
\text { (Low) }\end{array}$ \\
\hline Salinity & 7 & $\begin{array}{l}\text { Circulation, North Atlantic } \\
\text { source waters }\end{array}$ & Variable & $\begin{array}{l}\text { Not } \\
\text { determined }\end{array}$ & Medium & $\begin{array}{l}\text { Lower } \\
\text { values? } \\
\text { (Low) }\end{array}$ \\
\hline Salinity & 8 & $\begin{array}{l}\text { Circulation, North Atlantic } \\
\text { source waters }\end{array}$ & Variable & $\begin{array}{l}\text { Overall } \\
\text { increase in } \\
\text { Rockall } \\
\text { Trough } \\
\text { since mid- } \\
\text { 1970s }\end{array}$ & Medium & $\begin{array}{l}\text { Lower } \\
\text { values? } \\
\text { (Low) }\end{array}$ \\
\hline
\end{tabular}

